\title{
Messinian-earliest Zanclean tectonic-depositional dynamics of the Cinigiano-Baccinello and Velona basins (Tuscany, Italy)
}

\author{
Marco Benvenuti $(*),(* *)$, Giovanna Moratti $(* *)$, Federico Sani $(*),(* *)$, Marco Bonini $(* *)$, \\ Oriol L. Oms (***), Mauro Papini $(*)$, Lorenzo RooK $(*)$, Chiara Cavallina (*) \& Lorenzo Cavini (*)
}

\section{ABSTRACT}

The paper reports a revision of the tectonic-depositional evolution of the continental Cinigiano-Baccinello and Velona basins, located in the Amiata Volcano region, with special emphasis on the Messinian dynamics. Integration of facies analysis, magnetostratigraphy, and structural geology allowed a comparison of the evolution of these basins and a discussion of possible local to regional implications. At a local scale, crustal shortening, accommodated by thrust faults and related anticlines delimiting the basins, determined a dynamic physiographic and hydrographic scenario during the Messinian. Uplift of the tectonically-controlled shoulders was paired with pulses of subsidence in the basins that favoured the development of palustrine-lacustrine settings or endorheic alluvial plains. Stages of quiescent tectonics favoured fluvial incision of structural thresholds and the development of a south-directed drainage system, particularly developed during the late Messinian in coincidence with the Mediterranean Messinian Salinity Crisis The dominant fluvial and clastic depositional pattern recorded in these basins during such a regional scale event points to local tectonic activity of the Northern Apennines playing a major role than the climatic, eustatic and geodynamic factors that controlled the Mediterranean region.

KEY WORDS: Messinian, Cinigiano-Baccinello Basin, Velona Basin, Amiata Volcano.

\section{INTRODUCTION}

The Amiata Volcano (Tuscany, Italy) stands over wide areas covered by Late Neogene continental and shallow marine clastic deposits. These are the Cinigiano-Baccinello basin to the west, the Velona basin to the north, the Siena-Radicofani basin to the north and east and the Albegna basin to the south (fig. 1).

The distribution of these basins, locally filled with up to 2,000 meters of sediments (Radicofani basin), is strictly controlled by the structural features of the inner Northern Apennines chain made of NW-SE to N-S trending major thrusts and associated folds (fig. 1). The relations between basin development and the late Neogene kinematic evolution has fed a debate around opposite interpretations invoking either extensional (MARTINI \& SAGRI, 1993, and references therein; BROGI et alii, 2005;

(*) Dipartimento di Scienze della Terra, Università di Firenze, Italy. Corresponding author: ma.benvenuti@unifi.it Italy

$(* *)$ CNR, Istituto di Geoscienze e Georisorse, UOS Firenze,

(***) Departament de Geologia, Universidat Autonoma de Barcelona, Spain.
Brogi \& LiotTA, 2008; Brogi 2011) or compressional (BocCAlETTI et alii, 1999; BonINI et alii, 2014 and references therein) modes of basin activation and development. The different stratigraphic framework adopted by various authors for constraining the major stages of basins evolution played a crucial role in this debate. Informal lithostratigraphic subdivisions of the clastic basins' infill (DAMIANI et alii, 1980; LiOTTA \& SALVATORINI, 1994; LIOTTA, 1996; Bossio et alii, 1993), have been revised by the adoption of facies analysis, an improved chronologic constraint and the recognition and tracing of major unconformities (LANDI et alii, 1995; BENVENUTI et alii, 2001; BONINI \& SANI, 2002; GHINASSI, 2007; Rook et alii, 2011). This approach provided arguments for exploring in more detail the role of tectonics, that, joined to eustatic and climatic events, controlled the sedimentary patterns during the late Neogene (cf. BENVENUTI et alii, 2014).

This study aims to revise and discuss the tectonostratigraphic architectures of the Messinian-lowermost Zanclean deposits in the Cinigiano-Baccinello and Velona basins (fig. 1b) which are in large part represented in a new geological map published in this volume (MARRONI et alii, 2015). The present study integrates new magnetostratigraphic and structural data to those we published in previous papers (BENVENUTI et alii, 1994, 2001; LANDI et alii, 1995; Rook et alii, 2011; BonINI et alii, 2014). For the Velona basin previous (BONINI et alii, 1999) and new structural data are integrated to a new stratigraphic survey (MARRONI et alii, 2015, this volume) which revises pre-existing interpretation of the basin fill (RooK \& GHETTI, 1997; GHETTI, 1998).

A correlation of the two basin fills, not attempted before, provides a chronostratigraphic constraint to successive palaeogeographic and palaeohydrographic changes triggered by crustal shortening. The local tectonodepositional events, occurred well before the rising up of the Amiata Volcano, are finally discussed in the frame of the regional Messinian Salinity Crisis (RovERI et alii, 2014 for a recent review) for extending the significance of local depositional events to a wider scale.

\section{REGIONAL GEOLOGICAL FRAMEWORK}

The Northern Apennines are a NNW-trending arcuate fold and thrust belt that derived from the convergence between the Sardinia-Corsica block and the Adriatic plate in the Eurasia-Africa collisional zone (e.g., 

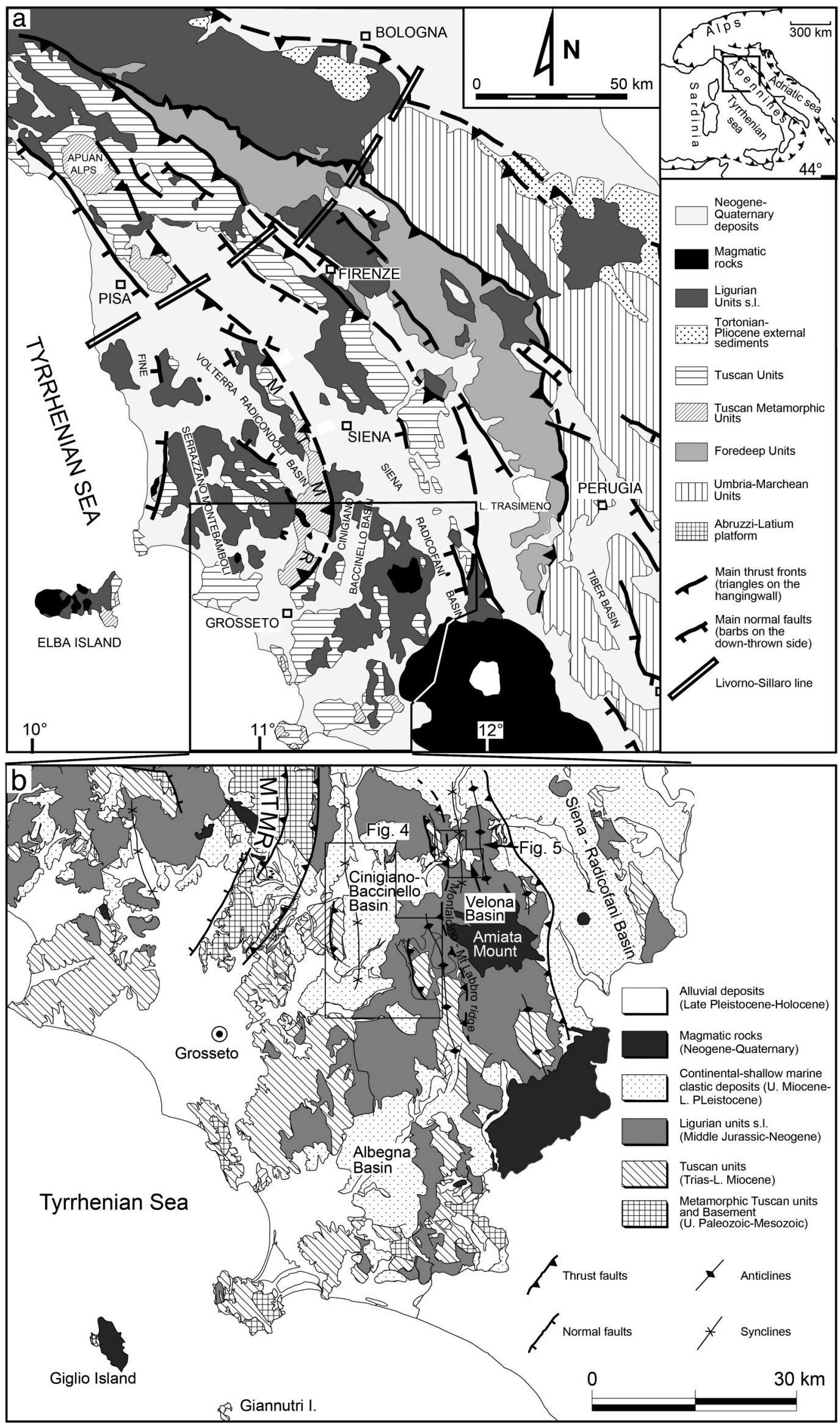

Fig. 1 - a) Geological map of the Northern Apennines, with location of fig. 1b; b) Geological map of Southern Tuscany, with indication of the studied Cinigiano-Baccinello and Velona basins and other Neogene-Quaternary basins of the area surrounding Mt. Amiata volcano. 
BoccaletTI et alii, 1971). The Apennine chain is made up by E-verging tectonic units, the uppermost of which are the ocean-derived Ligurian Units (fig. 1a). During continental collision late Oligocene to Miocene foredeep basins mainly filled by siliciclastic turbidite sediments formed at the front of the migrating chain. These sediments conformably overlie the Late Triassic-Eocene carbonate margin sequence of the Adriatic margin (Tuscan and Umbria-Marchean domains). Successively, the foredeep deposits were progressively (from $\mathrm{W}$ to $\mathrm{E}$ ) involved in thrusting and annexed to the chain (e.g. BoRToLotTI et alii, 1970; RICCI LUCCHI, 1986, and references therein). The Northern Apennines have been commonly subdivided into two sectors, an internal sector where marine and continental late Miocene to Quaternary hinterland basins, among which are the Cinigiano-Baccinello and Velona, unconformably overlay the already structured chain, and an external sector where thrusting processes are still active. The middle Miocene-Quaternary evolution of the Northern Apennines has been framed in an extensional tectonic context tied either to back-arc extension (e.g., TREVISAN, 1952; BocCALETTI \& Guazzone, 1972; MaLinverno \& RYAN, 1986; FACCENNA et alii, 2001; CARMINATI \& DOGLIONI, 2012) or to late orogenic gravity collapse (e.g., CARMIGNANI \& KLIGFIELD, 1990; CARMIGNANI et alii, 1994), mainly on the basis of indirect evidence, such as: presence of a thinned continental crust (CASSINIS et alii, 2005), high heath flow (Mongelli et alii, 1998; Della Vedova et alii, 2001) and positive Bouguer gravity anomaly (MARson et alii, 1998) together with occurrence of magmatism (SERRI et alii, 1993) in the hinterland area, accompanied by extensional seismicity, mostly in the axial zone (PoNDRELLI et alii, 2006). However, field mapping and structural analysis carried out in most of the hinterland basins show relationships between sedimentation and tectonics pointing to a compressive tectonic context for their evolution (e.g., BocCALETTI et alii, 1992, 1999; BONINI et alii, 2001). All the hinterland basins have common features such as: 1) a synformal-shape structure; 2) development between thrust-related anticlines which form the basin margins; 3) unconformities within the stratigraphic succession displaying gentler inclination proceeding from the basin margin to the centre of the basin and from older to younger sediments; 4) progressive unconformities indicating synsedimentary margin uplift; 5) well developed compressive deformations affecting the basin fill, made of reverse faults and folds; these latter always have an upright attitude which precludes a gravitational-driven origin; 6) these mesostructures allow palaeo-stress determinations that indicate shortening directions generally orthogonal to both the trend of the basins and the bounding thrustanticlines.

Despite both compressional and extensional structures affect the basin fill, usually extensional deformations post-dates the compressive ones.

The age of the main compressive pulses recorded by the basin's infill are basically coincident with the 6-4 Ma increase in exhumation rate determined through thermochronological data on metamorphic cores of the hinterland (BALESTRIERI et alii, 2011). This suggests an intimate connection between basin deformation and the activity of crustal thrusts producing the anticlinal ridges often delimiting the sedimentary basins.
STRATIGRAPHIC AND STRUCTURAL FRAMEWORKS OF THE UPPER TORTONIAN-MESSINIAN SUCCESSIONS IN THE CINIGIANO-BACCINELLO AND VELONA BASINS

\section{CINIGIANO-BACCINELLO BASIN: STRATIGRAPHY AND DEPO- SITIONAL EVOLUTION}

The Cinigiano-Baccinello (CB), one of the largest Neogene "central basins" (sensu MARTINI \& SAGRI, 1993), developed during the Late Miocene east of the Mid Tuscany Metamorphic Ridge (MTMR) (fig. 1) when this structural high separated western continental-marine from eastern fully continental basins. About $250 \mathrm{~m}$ of fluvio-lacustrine clastic deposits have been subdivided into two synthems, CB1 and CB2, which are described in detail in a companion paper (tab. 1; MARRONI et alii, 2015). The depositional evolution recorded by the two synthems is summarized below (fig. 2a).

Synthem CB1 (upper Tortonian-lower Messinian) documents an articulated evolution starting in the late Tortonian (figs. 2a and 3) with the deposition of alluvial and colluvial fans (unit CB1a, tab. 1; fig. 2a; BENVENUTI et alii, 2001; MARRONI et alii, 2015) at the base of the southern basin shoulder, made of a mudstone bedrock prone to develop sediment gravity flows.

These foot slopes were then occupied by poorly drained alluvial plains and successively by a shallow lake characterized by organic and carbonate deposition (unit CB1b, tab. 1; BENVENUTI et alii, 2001; MARRONI et alii, 2015), where endemic vertebrate remains (V0-V1 mammal faunas, RooK et alii, 2011) accumulated.

A terrigenous lake characterized by delta progradation from ESE (unit CB1c), replaced the previous environments (BENVENUTI et alii, 2001). The occurrence of an angular unconformity between units $\mathrm{CB} 1 \mathrm{c}$ and $\mathrm{CB} 1 \mathrm{~b}$, hints to basin deformation before the establishment of the terrigenous deltaic-lacustrine setting.

The shallow lakes were replaced after 7.5 Ma (early Messinian; fig. 3) by alluvial environments (unit CB1d, fig. $2 \mathrm{a} ; 3$ ) represented by alluvial fans prograding from the eastern basin margin into a muddy alluvial plain populated by a further endemic mammal fauna (V2 fauna; BENVENUTI et alii, 2001; RoOK et alii, 2011).

Successively the alluvial plain was crossed by an axial river that entered the basin from the north (unit $\mathrm{CB} 1 \mathrm{e}$, fig. 2) testifying its connection to wider catchments compared with the internal drainage of the previous stage. A mammal fauna, indicating a full biogeographic connection of the basin with mainland Europe (V3 fauna; BENVENUTI et alii, 2001; RoOK et alii, 2011), thrived in this environment.

A return to fluvio-lacustrine conditions occurred in the later early Messinian with deltaic sand axially supplied and spreading to the south in a shallow carbonate lake (unit CB1f; fig. 2a, see below; BENVENUTI et alii, 2001).

A drastic change occurred in the late Messinian when the basin was deeply dissected by a fluvial valley adjacent to the western $\mathrm{CB}$ margin and directed to the south (synthem CB2, fig. 2a). The valley was filled by fluvial conglomerates, sandstones and mudstones (units CB2a and CB2b) into two major stages (fig. 3).

During the early Pliocene the residual valley funnelled a sea ingression recorded by marine mudstone, referred to synthem CB3 (MARRONI et alii, 2015), resting unconformably on the CB2 deposits (see Bossio et alii, 1991). 
TABLE 1

Description of units, sub-units, lithological features, fossil content and depositional environments distinguished in the Cinigiano-Baccinello Basin.

\begin{tabular}{|c|c|c|c|c|}
\hline Units & Lithofacies & Lithological features & Fossils & Environment \\
\hline $\mathbf{C B 2 b}$ & & Reddish conglomerates and sandstones with textures and structures similar to CB2a & & To Alluvial fan \\
\hline CB2a & & $\begin{array}{l}\text { Clast-supported conglomerates in lenticular bodies. Massive to through-cross } \\
\text { stratified sandstones. Reddish to greyish massive mudstones. }\end{array}$ & & $\begin{array}{l}\text { From incised } \\
\text { valley fill }\end{array}$ \\
\hline \multirow{2}{*}{ CB1f } & $\mathrm{CB}_{1} \mathrm{f}_{1}$ & Well stratified yellowish sandstones with organic clays & $\begin{array}{l}\text { F2 molluscan fauna } \\
\text { (LoRENZ, 1968) }\end{array}$ & Shoalwater delta \\
\hline & $\mathrm{CB}_{1} \mathrm{f}_{2}$ & Well stratified whitish marls locally interbedded with pebbly sandstones & & $\begin{array}{l}\text { Shallow carbonate } \\
\text { lake }\end{array}$ \\
\hline \multirow[t]{2}{*}{ CB1e } & & $\begin{array}{l}\text { Grey-red-whitish banded mudstones with lenticular pebbly sandstones and } \\
\text { conglomerates }\end{array}$ & $\begin{array}{l}\text { European V3 } \\
\text { mammal fauna }\end{array}$ & $\begin{array}{l}\text { Alluvial plain with } \\
\text { channels and } \\
\text { floodplains }\end{array}$ \\
\hline & $\mathrm{CB}_{1 \mathrm{c}_{1}}$ & Massive to laminated greyish mudstones and brownish marls & $\begin{array}{l}\text { F1 molluscan fauna } \\
\text { (LoRENZ, 1968) }\end{array}$ & Terrigenous lake \\
\hline CB1c & $\mathrm{CB}_{1} \mathrm{c}_{2}$ & $\begin{array}{l}\text { Cemented yellowish massive, graded and cross-stratified sandstone and subordinate } \\
\text { greyish mudstone }\end{array}$ & $\begin{array}{l}\text { Scattered vertebrate } \\
\text { remains of the V1- } \\
\text { V2 mammal faunas }\end{array}$ & Shoalwater delta \\
\hline CB1b & $\mathrm{CB} 1 \mathrm{~b}_{2}$ & $\begin{array}{l}\text { Massive greyish silly clays making transition toward north to well stratified whitish } \\
\text { marls and calcareous sandstones }\end{array}$ & $\begin{array}{l}\text { Freshwater } \\
\text { molluscs }\end{array}$ & $\begin{array}{l}\text { Shallow organic- } \\
\text { carbonate lake }\end{array}$ \\
\hline CB1a & & Massive polymodal, matrix-supported greyish angular to sub-rounded conglomerate & & $\begin{array}{l}\text { Alluvial/colluvial } \\
\text { fan }\end{array}$ \\
\hline
\end{tabular}

W

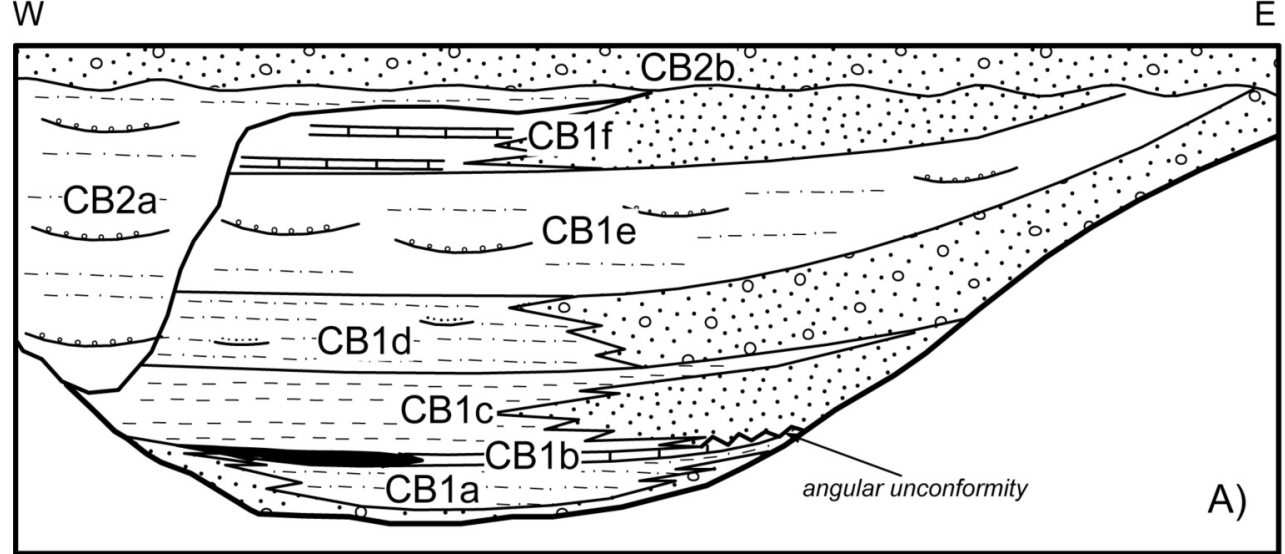

W

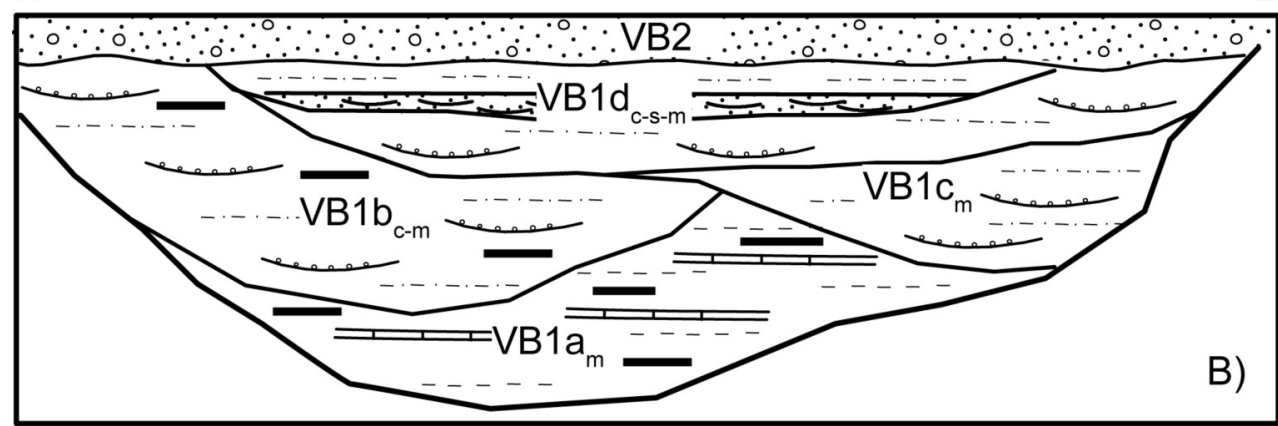

$\because \because$ alluvial-fan conglomerate, fluvial conglomerate,

fluvial conglomerate,
sandstone and mudstone

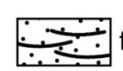

fluvial sandstone

$\because \because \vdots$ : deltaic sandstone
E

Fig. 2 - Stratigraphic schemes, roughly W-E oriented of Cinigiano-Baccinello and Velona basins $((a)$ and $(b)$, respectively), showing the different stratigraphic units and relationships among them, described in the main text and in MARRONI et alii (2015). 


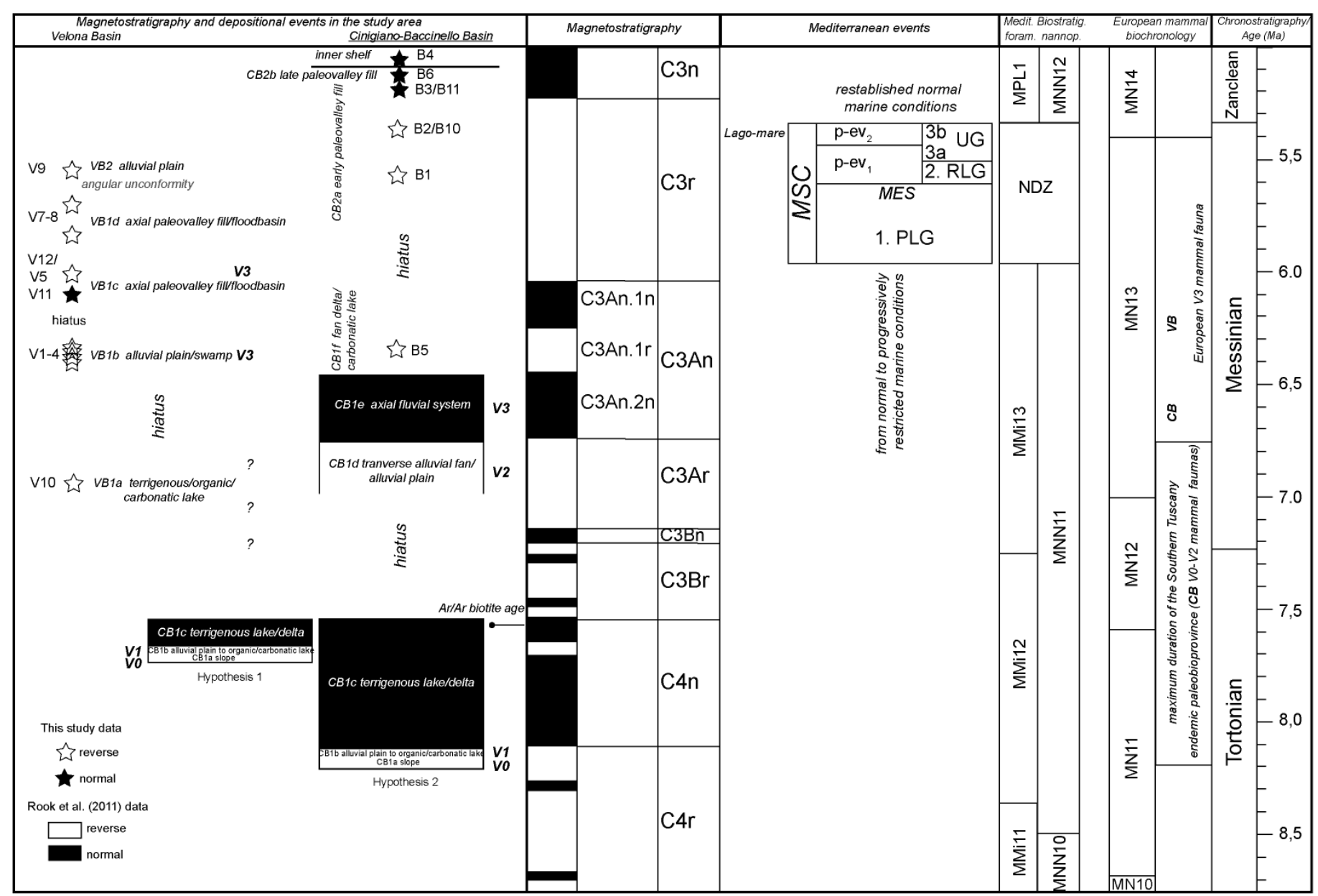

Fig. 3 - Comparison of magneto-stratigraphic and paleontological data between Cinigiano-Baccinello and Velona Basins. Samples for paleomagnetic analysis collected for this study are indicated with stars. Other paleomagnetic data are taken from RooK et alii (2011) Mediterranean events after RoverI et alii (2014): MSC: Messinian Salinity Crisis; 1.PLG: (stage 1) Primary Lower Gypsum; 2.RLG: (stage 2) Resedimented Lower Gypsum; UG: (sub-stages 3a and 3b) Upper Gypsum; MES: Messinian Erosion Surface.

VELONA BASIN: STRATIGRAPHY AND DEPOSITIONAL EVOLUTION

Similarly to the $\mathrm{CB}$, the Velona Basin (VB) is located east of the MTMR (fig. 1) and it is filled exclusively with continental deposits subdivided in this study in two main synthems, (VB1 and VB2). The latter are made of different units summarized here for their depositional significance (for details see tab. 2 and MARRONI et alii, 2015; fig. 2b). The chrono-stratigraphic calibration of these units is discussed later based on the results of a preliminary magneto-stratigraphic analysis (fig. 3 and see section 4).

In the early stages of deposition, the basin was characterized by a shallow terrigenous lake periodically affected by low sediment input when marly muds and vegetal debris deposited (lithofacies VB1a $\mathrm{a}_{\mathrm{m}}$, fig. 2b).

After the forced regression of the VB1a lake, marked by the incision of a fluvial valley, a river flowing to SSE brought to the cyclic deposition of conglomerates, sandstones and mudstones (lithofacies $V B 1 b_{c}-V B 1 b_{m}$, fig. 2b).

A second valley incision led to the development of a new fluvial system located eastward with respect to the previous one and still flowing to the SSE. A sandy-muddy succession (lithofacies $\mathrm{VB}_{\mathrm{c}} \mathrm{c}_{\mathrm{m}}$ ) records the infill of this valley.
The fluvial valley migrated again to the west and it was initially occupied by a gravelly stream (lithofacies

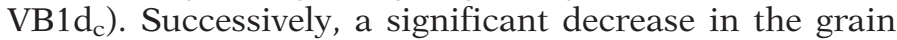
size of sediment supply favoured the development of a sandy braided river $\left(\mathrm{VB} 1 \mathrm{~d}_{\mathrm{s}}\right)$. Finally, a low-energy and poorly drained muddy floodplain $\left(\mathrm{VB}_{\mathrm{m}}\right.$, fig. $\left.2 \mathrm{~b}\right)$ replaced the fluvial channels.

Basin deformation brought to the folding and erosion of the VB1 deposits followed by the deposition of VB2 alluvial conglomerates, sandstones and mudstones (fig. 2b) which records a later reorganization of a drainage still directed to the south with possible development of an axially-fed alluvial fan.

\section{STRUCTURAL FEATURES AND KINEMATIC EVOLUTION}

\section{Cinigiano-Baccinello Basin}

Following the common model that considered the basins of the internal part of the Northern Apennines as developed in an extensional tectonic regime (TREVISAN, 1952), the CB was interpreted as a graben (GELMINI, 1969; DAMIANI et alii, 1980) or half graben (MARTINI \& SAGRI, 1993). An angular unconformity between inclined Miocene sediments and sub-horizontal Pliocene fill had 
TABLE 2

Description of units, sub-units, lithological features, fossil content and depositional environments distinguished in the Velona Basin.

\begin{tabular}{|c|c|c|c|}
\hline Lithofacies & Description & Fossils & Environment \\
\hline $\mathbf{V B 2}_{\mathbf{c}}$ & $\begin{array}{l}\text { Reddish-brownish conglomerates, massive sandstones and mudstones. Conglomerates } \\
\text { are arranged in lenticular beds made of clast-supported pebbles to cobbles }\end{array}$ & & $\begin{array}{l}\text { To Alluvial fan } \\
\text { From incised valley } \\
\text { fill }\end{array}$ \\
\hline $\mathbf{V B}_{1} \mathbf{d}_{\mathbf{m}}$ & Greyish massive to finely laminated mudstones and marls & $\begin{array}{l}\text { Rare poorly preserved } \\
\text { terrestrial molluscs }\end{array}$ & Flood basin \\
\hline VB1 $d_{\mathbf{s}}$ & $\begin{array}{l}\text { Yellowish coarse-grained to muddy sandstones arranged in massive to planar-through } \\
\text { cross laminated beds }\end{array}$ & & Sandy braided river \\
\hline $\mathbf{V B 1}_{\mathbf{c}}$ & $\begin{array}{l}\text { Clast-supported conglomerates in amalgamated and lenticular beds alternated with } \\
\text { greyish massive mudstones becoming predominant toward the top }\end{array}$ & & Torrential stream \\
\hline $\mathbf{V B 1} \mathbf{c}_{\mathbf{m}}$ & $\begin{array}{l}\text { Banded greyish-reddish-whitish mudstones with subordinated lenticular massive } \\
\text { pebbly sandstones }\end{array}$ & $\begin{array}{l}\text { Scattered V3 mammal } \\
\text { remains }\end{array}$ & $\begin{array}{l}\text { Low-energy, variedly } \\
\text { drained alluvial plain }\end{array}$ \\
\hline $\mathbf{V B 1} \mathbf{b}_{\mathbf{m}}$ & $\begin{array}{l}\text { Greysh-brownish mudstones and marls, organic mudstones and lignites and } \\
\text { subordinate massive fine-medium grained sandstones }\end{array}$ & $\begin{array}{l}\text { Freshwater/brackish } \\
\text { molluscs, ostracods } \\
\text { and V3 mammal } \\
\text { remains }\end{array}$ & $\begin{array}{l}\text { Low-energy, poorly } \\
\text { drained alluvial plain }\end{array}$ \\
\hline $\mathbf{V B 1}_{\mathbf{c}}$ & $\begin{array}{l}\text { Clast supported massive to planar and through cross-laminated fine-grained } \\
\text { conglomerates and massive pebbly sandstones arranged in lenticular to tabular bedsets }\end{array}$ & & Fluvial channels \\
\hline $\mathbf{V B 1} \mathbf{a}_{\mathbf{m}}$ & $\begin{array}{l}\text { Greyish mudstones and marls with intervening marly limestone and thin beds of } \\
\text { laminated lignite }\end{array}$ & & $\begin{array}{l}\text { Terrigenous lake } \\
\text { periodically affected } \\
\text { by organic and } \\
\text { carbonate deposition }\end{array}$ \\
\hline
\end{tabular}

already been recognized since the end of the 19th century (NovARESE, 1897). The latter evidence, together with the presence of folds (also reported by DAMIANI et alii, 1980) and reverse faults cutting the basin fill, led PASQUARE et alii (1983) to hypothesize that the CB was affected by a Messinian shortening event that marked the last compressive phase in the Northern Apennines hinterland. Since the early '90s, widespread specific structural analyses of both the basin fill and pre-Neogene substratum allowed to reconstruct the paleo-stress fields and define a compressional context for the CB evolution (BERNINI et alii, 1990; BocCALETTI et alii, 1992, 1999; LANDI et alii, 1995; SANI et alii, 2001). Recently, BONINI et alii (2014) constrained between ca 8.5 and $3.5 \mathrm{Ma}$ the lifespan of the compressive phases affecting the $\mathrm{CB}$, as well as the entire Northern Apennines hinterland. More specifically, tectonosedimentary studies reconstructed the CB fill architecture, where the CB1 deposits form a large-scale syncline between two $\sim \mathrm{N}$-S-trending ridges, the MTMR to the West and the Montalcino-Mt. Labbro ridge to the East (figs. 1 and 4). When visible, the contact between the basin fill and the pre-Neogene substratum is a stratigraphic onlap (LANDI et alii, 1995).

The Montalcino-Mt. Labbro ridge forms the eastern shoulder of the CB, between the basin and the Mount Amiata. The ridge is affected by important back-thrusts with a top-to-the-west movement, which cut the pre-existing structures, as identified between Castiglioncello Bandini and Stribugliano, and at Mount Buceto (BONINI et alii, 2014; fig. 4a and b). Along the eastern CB margin, $\mathrm{CB} 1 \mathrm{a}$ and $\mathrm{CB} 1 \mathrm{~b}$ units define well developed high-angle angular unconformities, with the beds progressively less inclined from bottom to top and basinward, consistent with the progressive syndepositional uplift of the eastern basin shoulder (LANDI et alii, 1995). From south to north, near Cana, the unit CB1d conglomerates form a W-verging backfold pair onto almost vertical Ligurian Units (fig. 4). In addition, at the Trasubbie and Melacciole creeks, strongly tilted and folded CB1a and b beds, unconformable over the pre-Neogene substratum, are sealed by less inclined CB1c deposits pointing to the activity of E-dipping blind backthrusts and associated backfolds (fig. 4a and b). North-north-west of Castiglioncello Bandini, west-verging folds affect CB2 conglomerates (fig. 4). Activity of blind backthrusts, possibly splaying from the Stribugliano-Mt Buceto system, therefore affected repeatedly the basin during Messinian - i.e., from the deposition of unit CB1b to unit CB2 (BonINI et alii, 2014).

At the western CB margin, the MTMR is a complex system of thrust-related anticlines involving and lifting the metamorphic Tuscan basement, as imaged from geophysical data (FINETTI et alii, 2001, and references therein). In the southern portion, a N-S trending E-dipping fault superposes the Tuscan over the Ligurian Units at Mount Cucco (fig. 4). Along this margin CB1d deposits directly onlap the pre-Neogene substratum. Progressive and angular unconformities are well developed within and between Messinian units, which show a general dip to the east (fig. 4, LANDI et alii, 1995), pointing to syndepositional margin uplift, possibly controlled by the Mount Cucco backthrust (BonINI et alii, 2014).

In the central part of the $\mathrm{CB}$, the Messinian units are intensively folded and affected by a km-scale top-to-theeast reverse fault, a splay of the deep rooted thrust systems, sealed by post-CB2 marine early Pliocene deposits (fig. 4). The activity of these structures is thus coeval with the last phases of backthrust activity at the eastern CB 


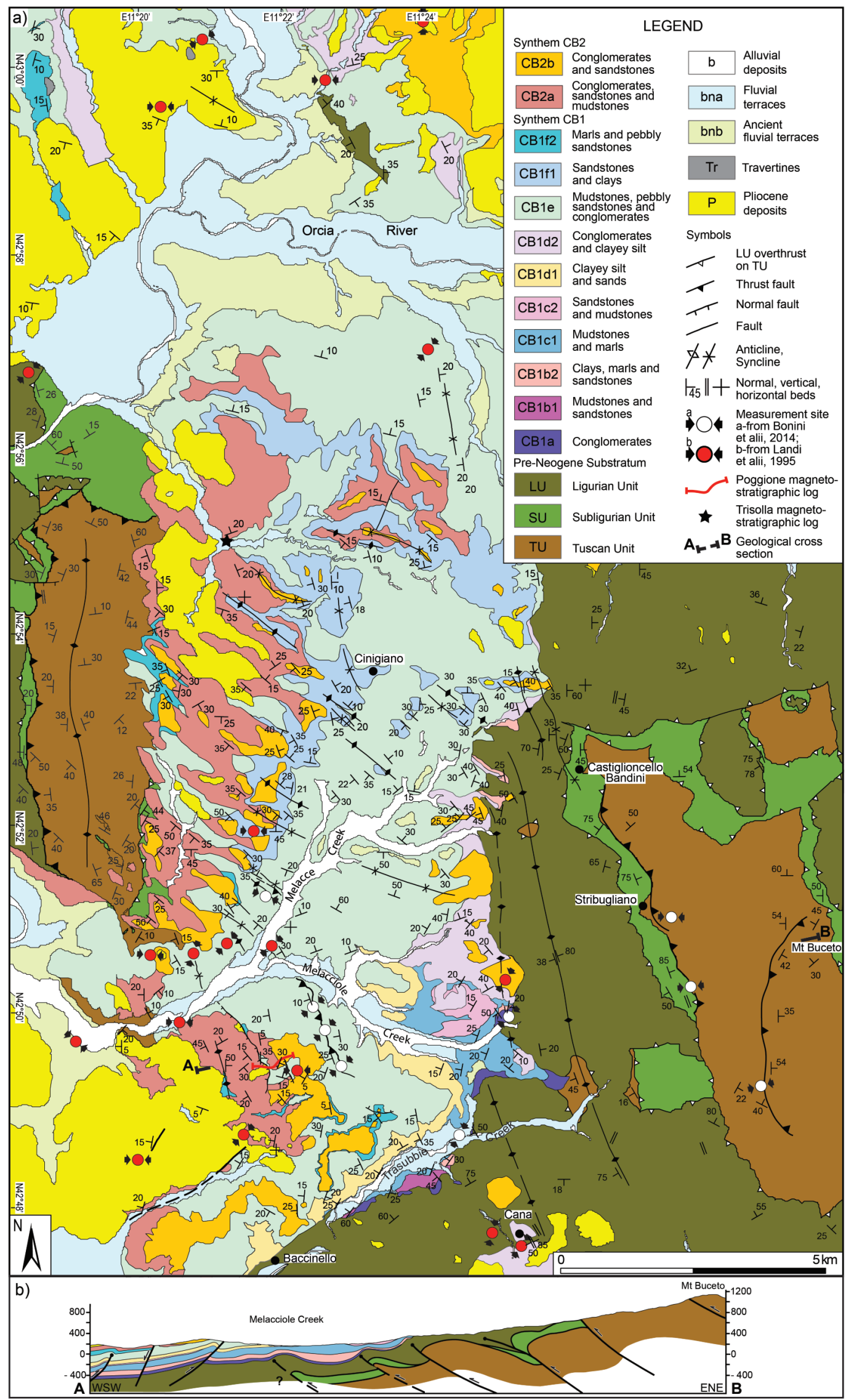

Fig. 4 - a) Geological map of the Cinigiano-Baccinello basin compiled from sheets of the Carta Geologica della Regione Toscana, and from BONINI et alii (2014), with revisions made for this work. Structural data are taken from LANDI et alii (1995) and from BoNINI et alii (2014). Location of the stratigraphic logs reported in fig. 7 is also indicated; $b$ ) Geological cross-section, trace in $a$ ). For the coloured figure, the reader is referred to the web version of the article. 
margin. The structural analysis carried out in the years at various measurement sites on the Messinian basin fill resulted in a general E-W to NE-SW directed sub-horizontal maximum shortening direction, which fits well with the NW-SE to N-S trend of both the major folds and reverse faults affecting the basin and of the thrusts and thrust-related anticlines bounding the basin (fig. 4).

NW-SE-trending high-angle normal faults affect both the northern and the central part of the CB (fig. 4). These structures displace the whole basin succession, including the Pliocene deposits, with a vertical separation generally lower than 50-60 m. Normal faults thus record the most recent deformation event.

\section{Velona Basin}

The VB develops as a gentle syncline between two $\mathrm{N}$-S-trending and E-verging thrust anticlines involving the Tuscan and Ligurian Units (BALly et alii, 1986; BONINI et alii, 1999), the Montalcino-Mt. Labbro ridge anticline to the west and the Ripa d'Orcia anticline to the east (figs. 1 and 5). The basin was considered a half-graben (MARTINI \& SAGRI, 1993; Rook \& GHetTI, 1997; GHetTI, 1998), with deposition controlled by a master normal fault on the north-western margin. A specific structural study identified (high-angle) angular unconformities, widespread contractional structures affecting the basin fill and a westward-directed depocenter migration during deposition of the oldest units (BONINI et alii, 1999). These findings allowed to propose that basin evolution was controlled by the kinematics of the two competing thrust anticlines at its margins (figs. 1 and 5).

A new stratigraphic analysis based on magnetostratigraphic sampling (see section 4), and a refining of the previous structural study have been carried out. The structural analysis of outcrop-scale structures within the basin fill, previously carried out by BoNINI et alii (1999), has been integrated by new data with the aim to reconstruct the Messinian paleostress directions. The new data consist of kinematic indicators on fault planes mainly collected in the eastern sector of the basin.

The gentle syncline is complicated by the occurrence of folds affecting both the sediments and the substratum, and no large normal faults controlling sedimentation are identified (fig. 5).

Unit VB1a crops out in the central-southern part of the basin, on both sides of the Orcia River. In this area were exploited two lignite levels intercalated in the unit. A well excavated in the mine area reached the total depth of $191.88 \mathrm{~m}$ (S. Giacomo well, CAMPANI, 1873; fig. 5b) and crossed at a depth between 90 to $110 \mathrm{~m}$ the two lignite levels showing a gentle dip towards the NW, as confirmed by the field mapping. Although the well is located with some uncertainties, these data have been used to construct the cross-section reported in fig. $5 \mathrm{c}$.

On the left bank, unit VB1a overthrusts with eastward vergence the VB1c sediments (fig. 6a) which, in turn, are folded together with the substratum (Piane Anticline, fig. 5a and c) and are affected by reverse faults and related folds. Along the Reciola creek (fig. 5), a topto-the-west backthrust affects Unit VB1c (fig. 6b-d), but no superposition relationships have been found with the above described thrust. The same back-thrust system extends to the north, and along a small valley which was analysed in detail by BoNINI et alii (1999; fig. 6f). Current exposures along the Orcia River allow defining cross-cutting relationships between back-thrusting and younger normal faulting (fig. 6e). At the northern margin, the Ligurian Units overthrust the VB1c deposits through an almost E-W trending top-to-the-south thrust (fig. 5a).

On the right bank of the Orcia River, VB1a deposits are overlain by the strongly deformed Unit VB1b. The deposits of this unit define an open syncline, and often show almost vertical beds related to a northwest dipping reverse fault and km- and outcrop-scale folds (BONINI et alii, 1999). VB1d deposits rest unconformably on the previous unit, forming the gentle $\sim \mathrm{N}-\mathrm{S}$-trending Ripi Syncline and the S. Giorgio anticline, with a subvertical eastern limb (BonINI et alii, 1999; fig. 5a and c).

The VB2 deposits are not involved in the folding and rest unconformably on the previous units through a nearly horizontal surface. The VB sediments seem to have been affected by two different shortening directions, (1) a dominant WNW-ESE to NW-SE directed $\sigma_{1}$, which accords well with the folds in the basin fill and the thrust anticlines at its margins, and (2) a subordinate compressive deformation with NE-SW to ENE-WSW directed $\sigma_{1}$ (figs. 5 and 6).

\section{MAGNETOSTRATIGRAPHIC DATA}

In order to provide new data suitable for the chronological calibration and for the stratigraphic correlation, a sampling for magnetostratigraphic analyses has been carried out in both the $\mathrm{CB}$ and VB deposits. In the $\mathrm{CB}$ sampling focussed on the upper portion of the succession including units CB1f and CB2a-b since the older CB1a-e units have been recently analysed for their magnetostratigraphic signature (Rook et alii, 2011). In the VB the magnetostratigraphic sampling and analysis represent the first attempt to provide a chronological constraint of the basin fill and, though preliminary, the obtained results provide arguments for a tentative correlation between the two basins. Measurement works, carried out at the Scientific-technical services at the Barcelona University (Paleomagnetism Laboratory, Institute of Earth Sciences, CSIC-UB), consisted in a wellestablished standard methodology (for details see RooK et alii, 2011).

\section{THE SAMPLED SECTIONS}

\section{Sections in the Cinigiano-Baccinello Basin}

The Poggione and Trisolla sections have been sampled in the CB due to the favourable exposures and the clear stratigraphic relationships. Specifically, the Poggione and Trisolla sections are located respectively downstream (i.e southward) and upstream (i.e northward) in the CB2a paleovalley (figs. 4 and 7). The vertical stacking of the CB2a deposits is almost identical in these sections, with conglomerate-mudstone stacked into two fining upward successions (CAVINI, 2010) (fig. 7b, c).

The 0,7 km-long SW-NE-oriented Poggione section is located about 3,8 km north of Baccinello (figs. 4 and 7a, b; CAVINI, 2010), and shows the relationships among units CB1e-f, CB2a-b and the unconformable Pliocene marine mudstones CB3 (fig. 7b). Two normal faults with vertical separation up to $50-60 \mathrm{~m}$ disrupt the lateral continuity 


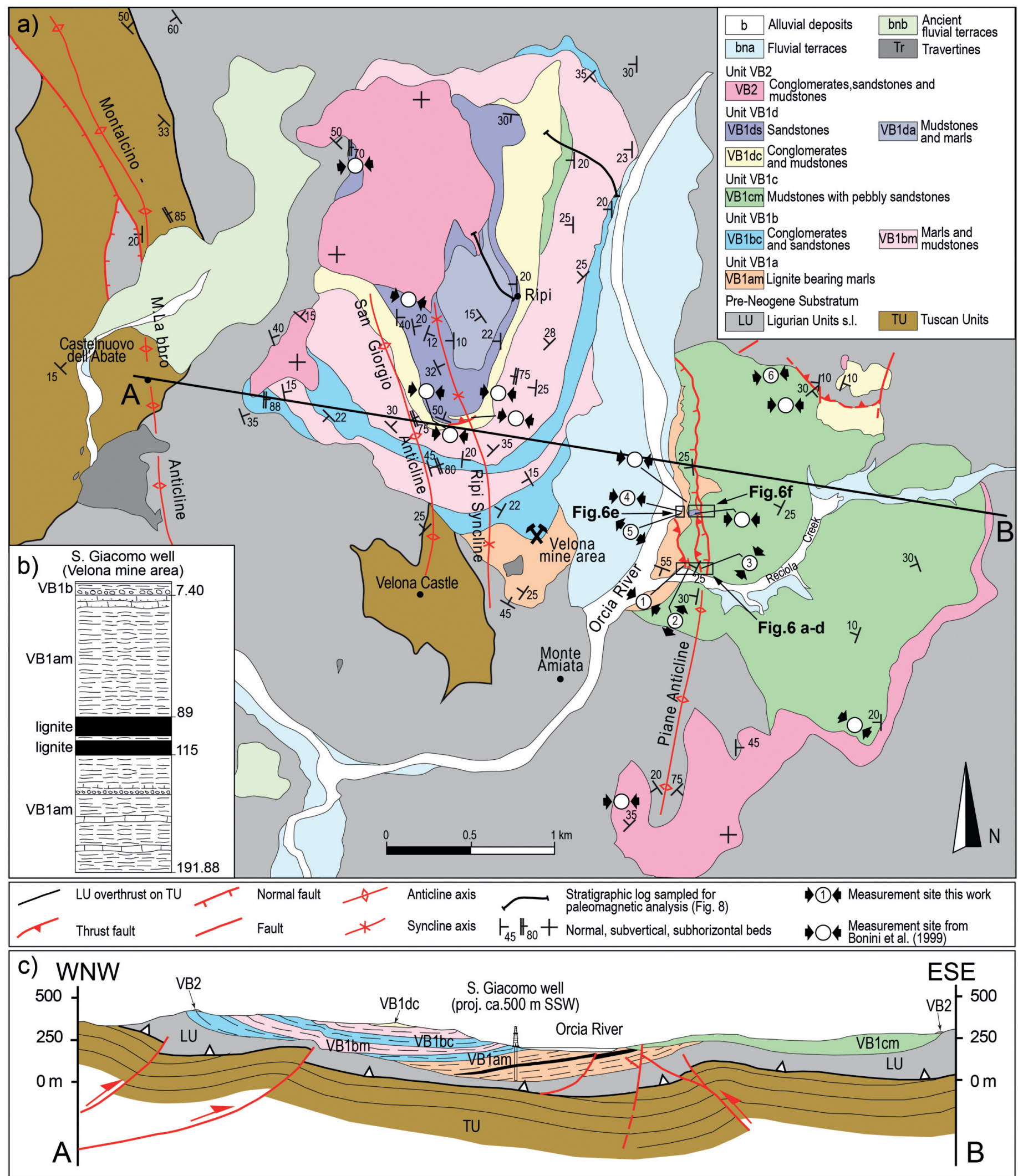

Fig. 5 - a) Geological map of the Velona Basin compiled from Rook \& GHETTI (1997), Bonini et alii (1999), and from sheets of the Carta Geologica della Regione Toscana with further revisions made for this work. Structural analysis derives from BoNINI et alii (1999) and has been integrated with data collected during this work. Location of stratigraphic logs reported in fig. 8 is also indicated; $b$ ) Stratigraphy of S. Giacomo well excavated in the Velona mine area (see location in $a$ )). The stratigraphy is simplified from CAMPANI (1873) and correlated to the units distinguished in the geological map; $c$ ) Geological cross-section, trace in $a$ ). For the coloured figure, the reader is referred to the web version of the article. 

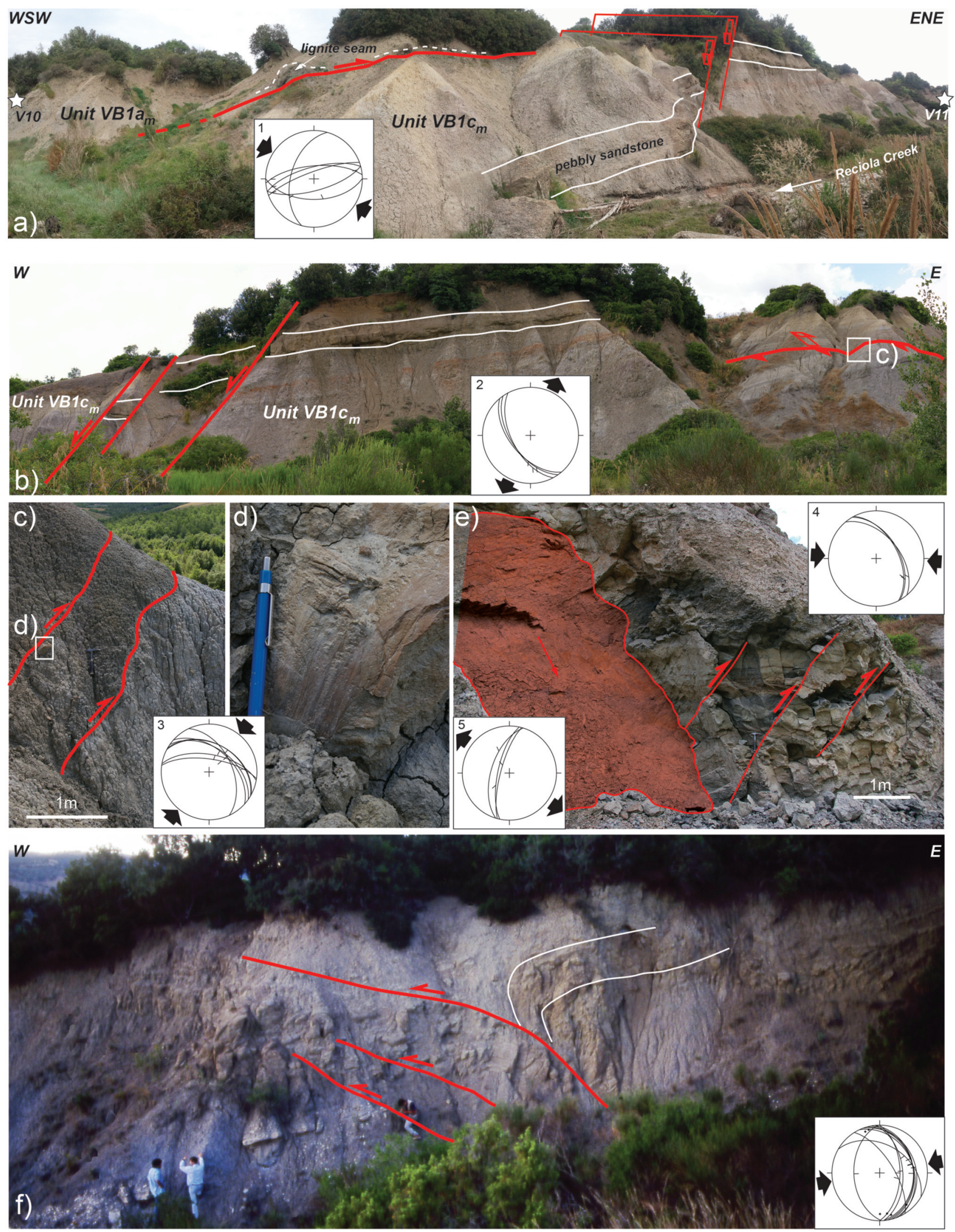

Fig. 6 - Outcrop-scale examples of structures affecting the Velona basin. The structures refer to outcrops located east of the Orcia river (for location see fig. 5). Stereonets of structural elements (Wulff net, lower hemisphere) are shown, whose location is reported in fig. 5 : a) thrust and normal faults along the Reciola creek; $b$ ) normal faults and back-thrust along the Reciola creek; details of $c$ ) back-thrust and d) kinematic indicators along the fault plane; $e$ ) outcrop along the Orcia river, showing mesoscopic reverse faults cut by a normal fault; f) outcrop north of the Reciola creek, with a well-developed back-thrust reported in BonINI et alii (1999). The photo (September 1997) shows folds and minor faults associated with the major thrust-related fold; no longer visible outcrop. For the coloured figure, the reader is referred to the web version of the article. 


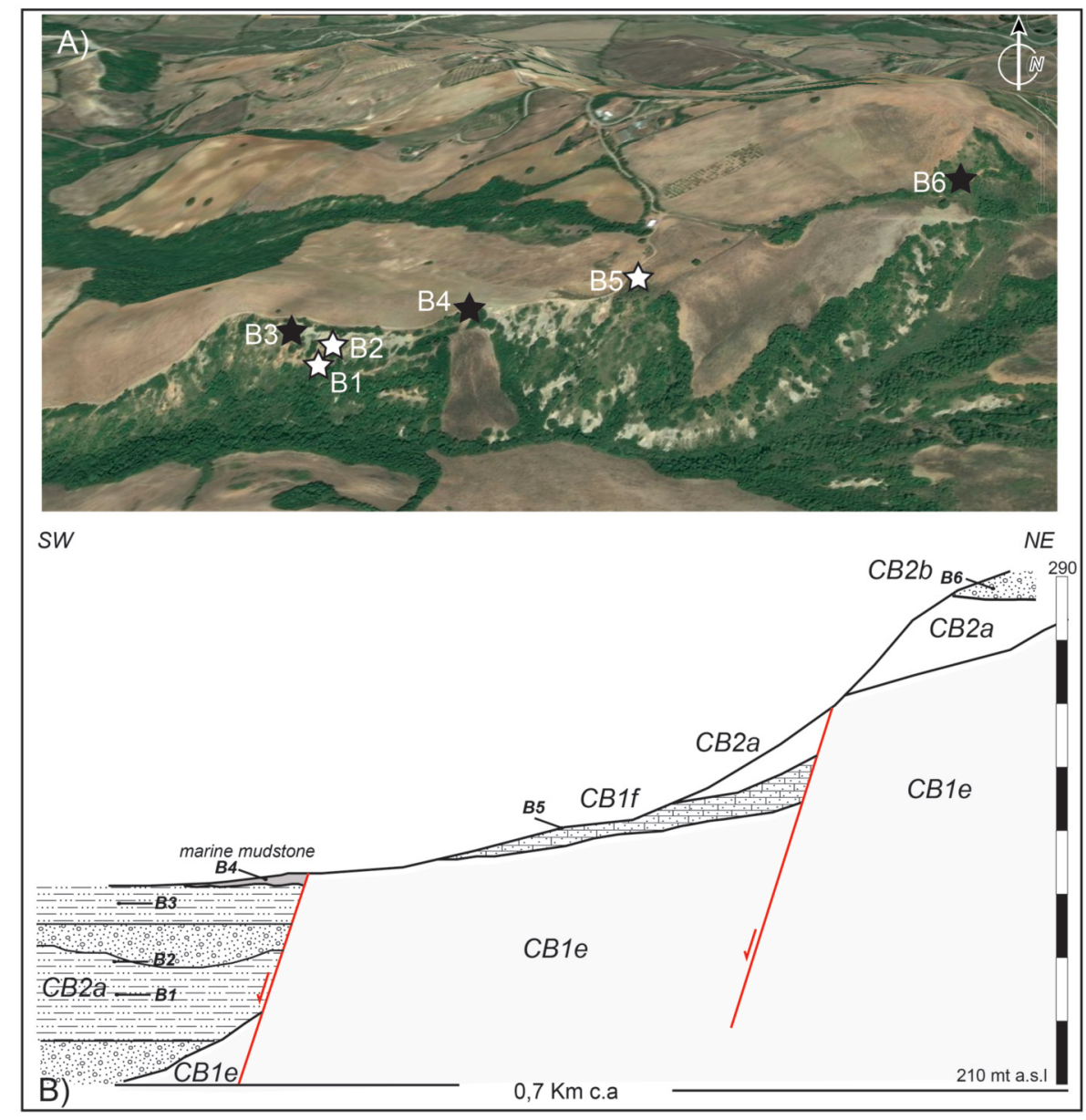

Fig. 7 - Location of paleomagnetic samples in the Cinigiano-Baccinello basin: $a$ ) panoramic view of the sampled Poggione section (image from Google Earth TM). White and black stars (also in $c$ ) indicate the reverse or normal polarity, respectively (see fig. 3); b) Schematic Poggione cross-section approximately along the sampled line, with indication of the sampled stratigraphic units; $c$ ) Logs of the Poggione and Trisolla sections with stratigraphic correlations (location of sections in fig. 4).

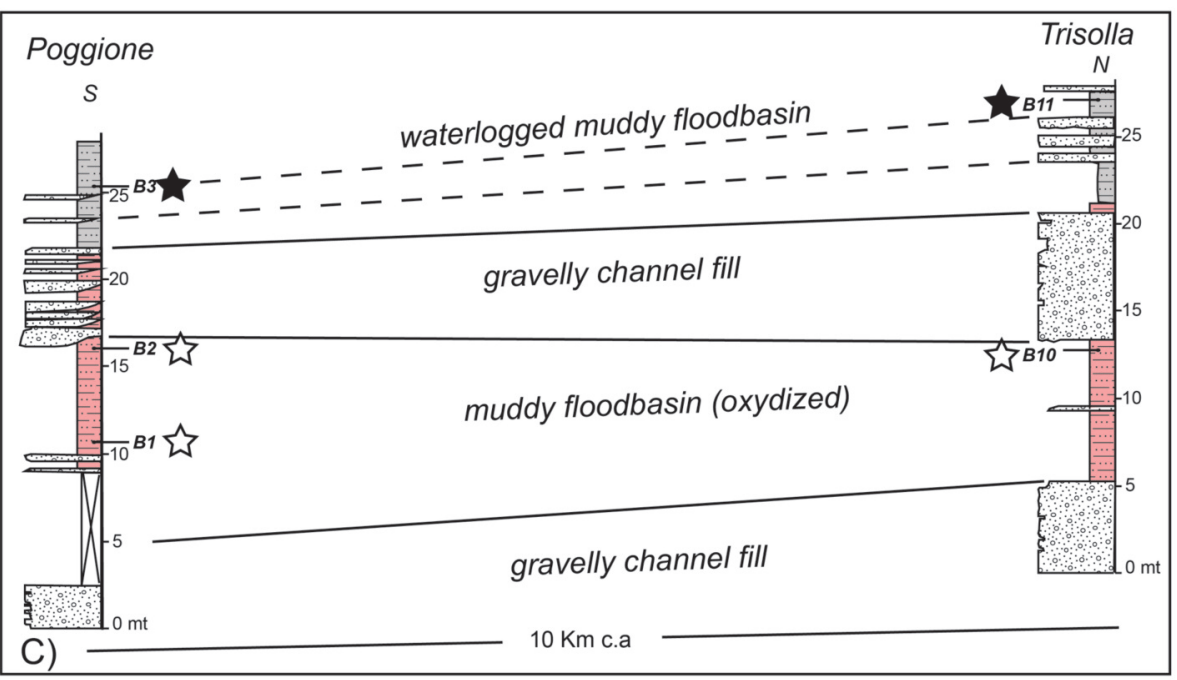

of the CB2 paleovalley incised into the CB1e-f deposits. Six samples (B1-6) have been collected, specifically: B1-3 within reddish-greysh mudstones interbedded with conglomerates of unit CB2a, B4 in the Pliocene mudstones, $\mathrm{B} 5$ in the marls of unit $\mathrm{CB} 1 \mathrm{f}$ and $\mathrm{B} 6$ in reddish muddy sandstones of unit CB2b (fig. 7a).

In the Trisolla section, located about $10 \mathrm{~km}$ northward, only the CB2a deposits crop out in which two samples, B10-11, were collected in an almost equivalent stratigraphic position of samples B2 and B3 (fig. 7c; CAVINI, 2010).

\section{Sections in the Velona Basin}

Two sections were selected in the Velona Basin (figs. 5 and 8). The Casotto-Ripi section, on the west side of the Orcia River, coincides in the lower portion with the Fosso Casotto section described by GHETTI et alii (2002). In the present study the section has been extended to most of synthem VB1 (lithofacies VB1 $b_{m}$ to VB1 $d_{m}$, fig. 8) and the basal portion of synthem VB2, where nine samples (V1-9) were collected. The second section, Reciola-Gretoni, is located east of the Orcia River, where three sam- 

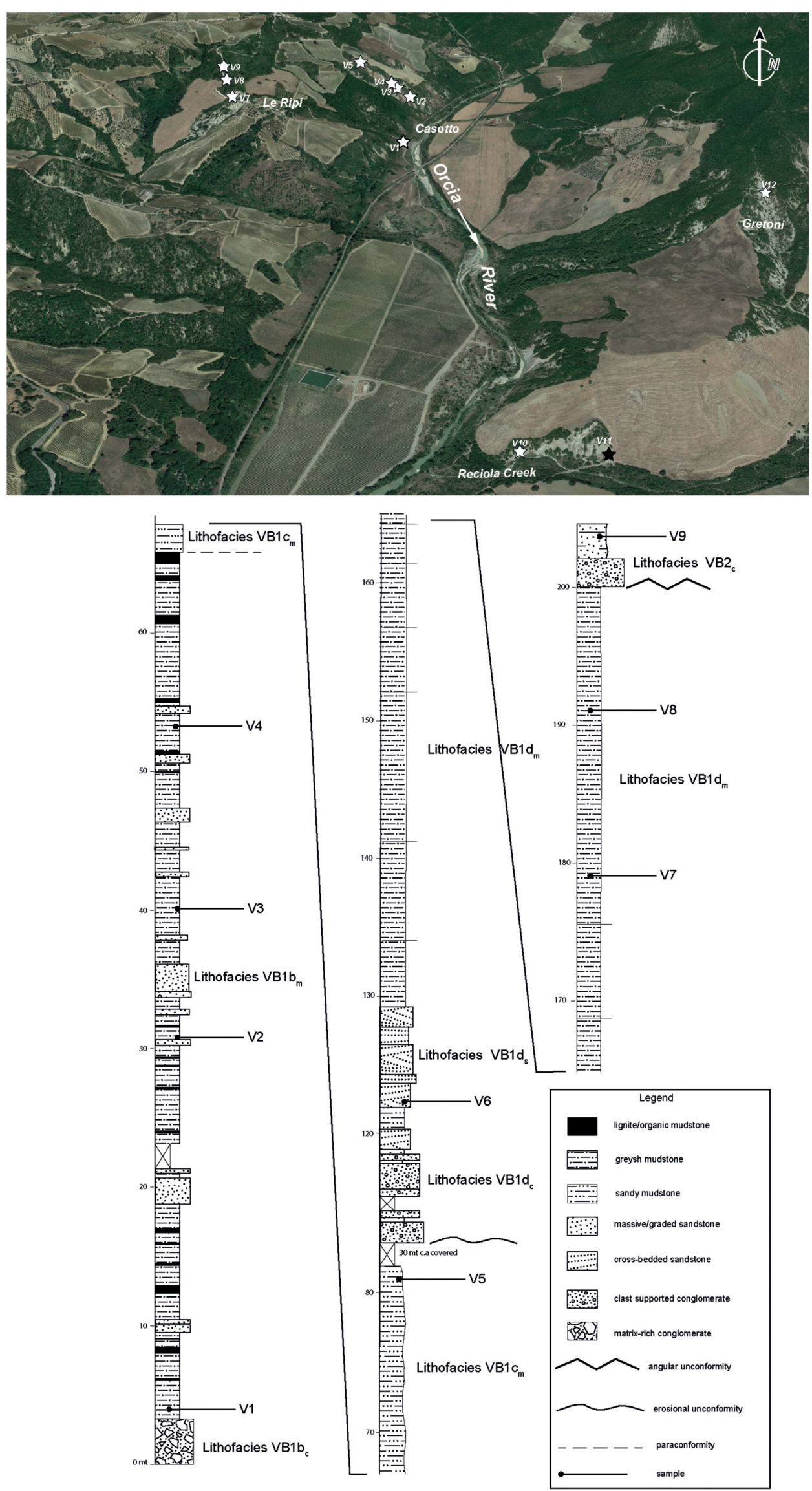

Fig. 8 - Location of paleomagnetic samples in the Velona basin: a) panoramic view of the northern part of the basin and indication of sampled localities (image from Google Earth TM). White and black (V11) stars indicate the reverse or normal polarity respectively; $b$ ) Stratigraphic log measured on the right of Orcia River between Casotto and Ripi (fig. 5), with indication of the different sampled stratigraphic units. 
ples were collected (fig. 8). The section encompasses the VB1am deposits (sample V10) that are unconformably overlain by lithofacies VB1c $\mathrm{c}_{\mathrm{m}}$ (sample V11) and $\mathrm{VB} 1 \mathrm{~d}_{\mathrm{c}}$ (sample V12).

\section{MAGNETO-STRATIGRAPHIC CONSTRAINT FOR A CHRONO- STRATIGRAPHIC CALIBRATION \\ Cinigiano-Baccinello Basin}

The six samples collected in the $\mathrm{CB}$ extend the magnetostratigraphic record to comprise the uppermost portion of the basin fill resulting in a quite consistent pattern of magnetic inversions compared with previous data (Rook et alii, 2011; fig. 3). The latter suggested the attribution to the normal subchron C3An.2n (early Messinian) for the fluvial deposits of unit CB1e bearing the European V3 mammal fauna, this unit being the youngest analysed by Rook et alii (2011; fig. 3).

- Sample B5 (Poggione section) collected in the CB1f marls yielded a reverse magnetization that is referred to the subchron C3An-1r.

- Synthem CB2 displays a pattern of magnetization starting from the reverse samples B1-2 (Poggione) and B10 (Trisolla) to normal samples B3 (Poggione)-B11 (Trisolla) (figs. 3 and 7). Sample B6 collected in unit $\mathrm{CB} 2 \mathrm{~b}$ resulted again in normally magnetized as well as the overlying marine mudstones (sample B4), both from the Poggione section (fig. 7).

Taking into account that synthem $\mathrm{CB} 2$ rests over $\mathrm{CB} 1$ through a high-relief erosional surface related to deep valley incision the related hiatus may explain the missing of the normal subchron C3An.1n, even though insufficient sampling cannot be excluded. The persisting reverse record along most of the $\mathrm{CB} 2 \mathrm{a}$ valley fill points to chron $\mathrm{C} 3 \mathrm{r}$, which characterizes the upper Messinian-earliest Zanclean. The uppermost samples of unit CB2a, CB2b and the marine mudstones resulted normally magnetized, hinting to a correlation with chron C3n of the early Zanclean. Biostratigraphic studies (Bossio et alii, 1991) ascribed similar mudstones sampled not far from the Poggione section to the MPl1-MNN12 biozones of the Mediterranean foraminifer and nannoplancton biostratigraphy, respectively (fig. 3), in agreement with the results of this study.

The preliminary magnetostratigraphic calibration suggests that the CB2 paleovalley was possibly incised and fully developed during the late Messinian and lasted until the earliest Zanclean, up to the flooding by the sea ingression (Bossio et alii, 1991).

\section{Velona Basin}

In the VB the eleven samples yield a stable analytical response and suggest the following tentative calibration (fig. 3):

- The reverse lowermost sample V10 from the lacustrine lithofacies $\mathrm{VB} 1 \mathrm{a}_{\mathrm{m}}$ does not confidently correlate to any specific magnetostratigraphic intervals. These deposits are unconformably overlain by the fluvial lithofacies $\mathrm{VB} 1 \mathrm{~b}_{\mathrm{c}}-\mathrm{VB} 1 \mathrm{~b}_{\mathrm{m}}$ and represent the exposed uppermost portion of thick buried lignite-bearing lacustrine deposits (CAMPANI, 1873), which (similarly to units CB1b-c) may extend back in the late Tortonian, hence to any reverse intervals between $\mathrm{C} 4 \mathrm{n}$ and C3Ar (fig. 3).
- The reverse V1-4 samples collected in lithofacies $\mathrm{VB} 1 \mathrm{~b}_{\mathrm{m}}$ encompass the portion of the succession bearing a V3-like mammal fauna (Rook \& GHETTI, 1997; GHETTI et alii, 2002). Since the V3 fauna in the CB correlates to the normal C3An.2n and the preceding reverse C3Ar is recorded in the $\mathrm{CB} 1 \mathrm{~d}$ unit bearing the endemic V2 fauna (Rook et alii, 2011), the equivalent V3 remains in the VB are quite confidently related to C3An.1r. This is not in contrast with faunal composition of mammal assemblage from both Cinigiano-Baccinello Basin V3 and Velona Basin mammal faunas. Although the two assemblages have no species in common, the faunas are composed of continental European taxa, and are both correlatable to the Messinian mammal assemblages characterizing MN13 latest Miocene Italian fossiliferous sites along the northern Apennines, from Piedmont (Ciabot Cagna, Moncucco and Verduno; CAVAllo et alii, 1993; ANGELONE et alii, 2011; COlOMBERo et alii, 2014) to Romagna (Brisighella; RooK \& BERNOR, 2013) and Tuscany (Borro Strolla; ABBAZzI et alii, 2008; fig. 3).

- The normal polarity V11 sample collected in the basal $\mathrm{VB} 1 \mathrm{c}_{\mathrm{m}}$ deposits marks the large hiatus recorded on the left bank of the Orcia River where these deposits rest erosively on lithofacies $\mathrm{VB} 1 \mathrm{a}_{\mathrm{m}}$. The correlation proposed in this study (fig. 2b) shows that the topmost VB1 $\mathrm{c}_{\mathrm{m}}$ rests through a paraconformity on lithofacies $\mathrm{VB} \mathrm{b}_{\mathrm{m}}$ (fig. 5), outlining the high-relief erosional surfaces bounding units VB1b-c. Under this assumption the normal V11 is tentatively ascribed to the C3An.1n subchron whereas the uppermost reverse deposits (sample V5, fig. 8) of lithofacies $\mathrm{VB} 1 \mathrm{c}_{\mathrm{m}}$, are referred to $\mathrm{C} 3 \mathrm{r}$ (fig. 3). On the east of the Orcia River, RooK \& GHETTI (1997) reported scanty V3-like vertebrate remains from lithofacies $V B 1 c_{m}$. Based on the proposed stratigraphic correlation, this implies that the non-endemic V3 fauna of southern Tuscany thrived in the VB during most of the Messinian, in agreement with its correlation with the MN13 unit of the European mammal biochronology (fig. 3).

- A reverse polarity also persisted in the overlying samples V12 and V7-8 collected respectively in the VB1d (left bank of Orcia River), in the VB1 $\mathrm{d}_{\mathrm{m}}$ and in the basal VB2 deposits (right bank of Orcia River), supporting again a reference to $\mathrm{C} 3 \mathrm{r}$ and thus to the late Messinian.

Summing up, the preliminary magnetostratigraphic data support the stratigraphic framework defined by facies analysis. Specifically these data suggest that the exposed upper half of the basin fill may encompass the whole Messinian with a multiple development of fluvial valleys that occurred during the late Messinian.

\section{DISCUSSION}

\section{DEPOSITIONAL DEVELOPMENT AND DEFORMATION DURING THE MESSINIAN}

The stratigraphic and structural analysis integrated with magneto-stratigraphic data, allow us to delineate the evolution through time of the Cinigiano-Baccinello and Velona Basins during the Messinian. The CB also bears a late Tortonian stage of development dominated by palustrine-lacustrine deposition, described and discussed in detail in previous papers (BENVENUTI et alii, 2001; RoOK et alii, 2011). The lack of dating and the limited outcrops 
prevent to correlate similar palustrine-lacustrine deposits buried in the VB (CAMPANI, 1873) which could have formed in a coeval tectono-depositional phase.

A tentative correlation of the two basins, in terms of depositional and palaeogeographic scenarios that occurred in time, is proposed for the Messinian. The depositional environments developed in the different stages of the basin's evolutions account for two basic states: $a$ ) closed internal drainage determining palustrine-lacustrine or endhoreic alluvial conditions, which hint to internal basin subsidence driven by the activity of the bounding structures (fig. 9a); $b$ ) open drainage favouring the connection of relatively wide fluvial catchments, generally draining southward, during which the CB and VB were basically fluvial by-pass areas. At stage $b$ ) the bounding structures were probably quiescent or moderately active allowing fluvial incision to undercut existing structural thresholds which evidently isolated the basins in the previous stages (fig. 9b).

Cyclic or single fining-upward trends within the paleovalley fills of the two basins, suggest that after valley incision, facilitated by tectonic quiescence, the filling occurred through repeated or single rising of base-level possibly regulated by renewed basin subsidence under active tectonics (cf ALLEN \& HELLER, 2012). Climate fluctuations affecting the rates of sediment production and supply to the fluvial systems, may have forced the observed transition from gravelly-sandy bed rivers flowing in the valley bottoms during the early filling, to lowenergy and poorly drained floodbasins typical of the late filling. Nevertheless, we suggest that a primary control on this recurring pattern of valley fill may have been represented by a tectonically-driven rising of fluvial base level.

Under these assumptions and with the support of the magnetic polarity pattern described above, the following correlation and evolution is traced for the Messinianearly Zanclean basin development (figs. 3, 9).

- In the CB, the first Messinian depositional unit is represented by the magnetically reverse deposits of unit CB1d pointing to an endhoreic alluvial plain which replaced the lacustrine environments that lasted up to the Tortonian-Messinian transition (figs. 3 and 9d). The biogeographic isolation indicated by the endemic V2 fauna, seems positively related to the physiographic confinement recorded by these deposits due to the tectonic activity of both the Montalcino-Mt. Labbro thrust related anticline, to the east, and the MTMR and/or the Mt. Cucco backthrust to the west. A direct correlation with the VB deposits is not possible, though also the lacustrine $\mathrm{VB} 1 \mathrm{a}_{\mathrm{m}}$, record internal drainage conditions and yield a reverse polarity.

- In the CB, unit $\mathrm{CB} 1 \mathrm{e}$ points to a change in the alluvial development recording an axial, south-flowing river system characterized by low-sinuosity channels and adjacent floodplains (fig. 9e). This environment testifies to wide fluvial connections associated with quiescent tectonic activity, thus to the temporary removal of the thresholds that isolated the basin in the previous stages. These normal-polarized deposits bear the European V3 mammal fauna that in turn record a regional paleo-biogeographic connection between the previously isolated southern Tuscany and the Europe mainland throughout the newly emerged northern Apennine chain (BENVENUTI et alii, 2001). The normal interval recorded in the $\mathrm{CB}$ is apparently missing in the VB, possibly because of the erosion related to the incision of the VB1b valley.

- Deltaic-lacustrine conditions developed in the CB bringing to the deposition of the CB1f unit. The latter records the progradation of a sandy delta fed from north into a basin evidently re-closed to the south, where a shallow carbonate lake developed and then transgressed the delta northward (fig. 9f). These conditions are likely controlled by a new phase of activation of the roughly N-S trending structures delimiting the basins such as the Montalcino-Mt. Labbro ridge and the MTMR. The reverse single sample B5 collected in the marls overlying the delta sandstones suggests that this scenario existed at the end of the early Messinian. A correlation is proposed with unit VB1b which documents the cyclic filling of a western fluvial valley (figs. $2 \mathrm{~b}, 3$, 9f). In particular, the upper portion of $\mathrm{VB} 1 \mathrm{~b}_{\mathrm{m}}$ resulted inversely polarized as sample B5. The marked increase in accommodation which caused accumulation of lacustrine marls in the CB could find its equivalent into the fine grained infill of the VB valley suggesting a tentative correlation of the two basins during this stage.

- The latest early Messinian, represented by the normal C3An-1n subchron (fig. 3), is missed in the CB, possibly within the hiatus separating $\mathrm{CB} 1$ and $\mathrm{CB} 2$ synthems. On the contrary, it is recorded in the VB by the basal $\mathrm{VB}_{1 \mathrm{c}_{\mathrm{m}}}$ deposits (sample V11, fig. 8) that again represent the early valley infill that continued in the late Messinian and whose roughly N-S orientation was strongly controlled by the activity of a backthrust associated with the Ripa d'Orcia thrust-related anticline, which delimits the VB to the east (figs. 2b, 3, 9g).

- The lower portion of CB2a, the VB1d valley fill and the basal VB2, all record a reverse polarity that reasonably correlates to the $\mathrm{C} 3 \mathrm{r}$ chron characterizing the late Messinian. In the CB the final filling of the CB2 paleovalley, recorded by alluvial-fan deposits, and its subsequent marine flooding occurred in the $\mathrm{C} 3 \mathrm{n}$ chron correlated to the early Zanclean. In the Velona Basin, the VB2 deposits referred to an alluvial fan overfilling the VB2 incised valley and angularly overlying unit VB1, possibly developed within the two oppositely-verging Montalcino-Mt. Labbro and Ripa d'Orcia thrust anticlines (fig. 9h).

\section{The Late Messinian PalaeOHydrography OF THE AMIATA AREA}

The stratigraphic revision and correlation, supported by magnetostratigraphic data, suggests that a southward directed hydrography developed during the late Messinian west and north of the present Amiata Volcano. Repeated incision of deep fluvial valleys occurred in the two basins within the reverse chron C $3 r$ encompassing the late Messinian and the earliest Zanclean. This conclusion partially supports an early lithostratigraphicallybased generic attribution to the Mio-Pliocene of the clastic sediments ascribed here to $\mathrm{CB} 2$ and to the VB1-2 (P1-M3 unit of JACOBACCI, 1965; Pcg and M3-Pcg units of MotTA, 1969). From a paleogeographic perspective, the valley fills recognized in the physical stratigraphy of the $\mathrm{CB}$ and VB were parallel-trending, and delimited by the N-S MTMR and Montalcino-Mt. Labbro ridges that bounded the two basins (fig. 9g, h). The available geological maps of the area between the two basins (LANDI et alii, 1995; GHINASSI, 2007) and coinciding with the pre- 


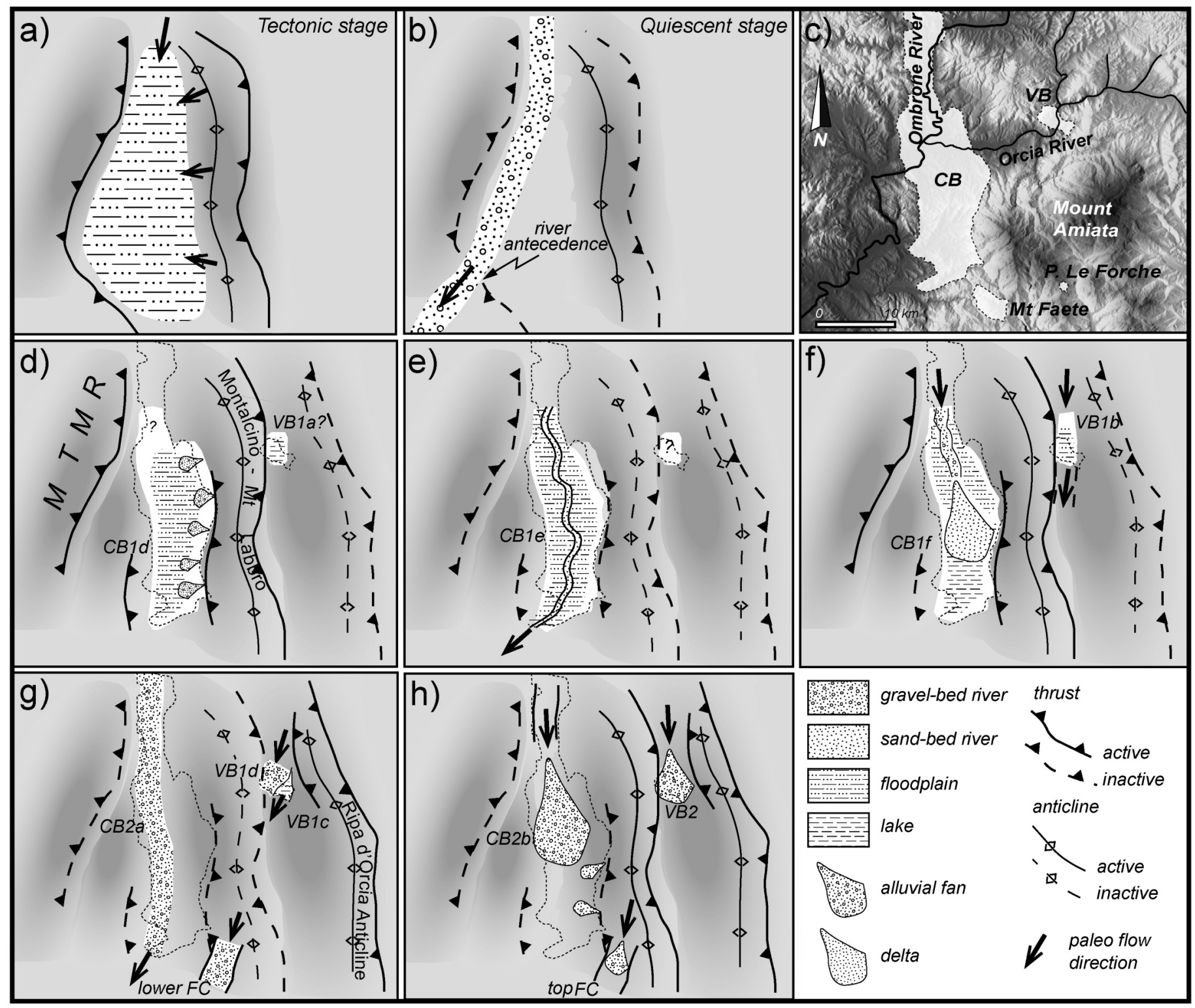

Fig. 9 - Cartoon showing the main steps in the tectono-stratigraphic evolution of the Cinigiano-Baccinello and Velona basins: $a$ ) Schematic representation of a tectonic stage. The basin is characterized by closed internal drainage determining palustrine-lacustrine or endhoreic alluvial conditions tied to internal basin subsidence driven by the activity of the bounding structures; $b$ ) schematic representation of a quiescent stage: open drainage favouring the connection of relatively wide fluvial catchments. During these conditions the bounding structures were probably quiescent or moderately active allowing fluvial incision to undercut existing structural thresholds; $c$ ) Digital Elevation Model of the study area showing the current extent of the deposits of the basins (light grey). Panels $d$ )-h) report the evolutionary stages of deposition of the different stratigraphic units and the activity of structures controlling sedimentation (for a detailed description see text).

sent terminal reach of the Orcia River, do not report Messinian deposits showing a shallow marine succession (synthem CB3, MARRONI et alii, 2015) resting directly on the pre-Neogene substratum. Not excluding that Messinian deposits may be buried below the Pliocene or eroded before the marine flooding, this evidence is here considered to support marine the hypothesis of a missing direct connection between the $\mathrm{CB}$ and VB during the Late Miocene. In such a paleogeographic scenario the N-S trending valleys acted as by-pass zones flushing part of the clastic load in storage areas toward the south. Isolated outcrops of conglomerates previously ascribed to a generic Mio-Pliocene (JACOBACCI, 1965; MotTA, 1969), occur indeed south and east the studied basins. These may represent preserved portions of such a south- directed drainage network disintegrated by later rise of the Amiata Volcano. A prominent outcrop is in the Mount Faete area, located $4 \mathrm{~km} \mathrm{SE}$ the CB (fig. 9c), where reddish conglomerates up to 250 meters thick rest unconformably over the Ligurian bedrock and on the folded CB1d deposits near Cana village (fig. 4; BonINI et alii, 2014). The Mount Faete conglomerates have been recently mapped as two distinct sub-units, ascribed to the Messinian and early Zanclean, respectively, and separated by an angular unconformity (Carta Geologica della Toscana, 2010). These deposits are here interpreted as the remnant of a deep trunk valley linked to the drainage network developed in the area and thus share the stratigraphic position of the CB2 synthem between the end of the Miocene and the early Pliocene. It is here stressed the 
strong relation between the river network and the structural trends. The southward directed major rivers in the areas were evidently funnelled by the N-S trending thrust anticlines that were tectonically active between the late Messinian and the early Zanclean. Uplift of the structural highs and localized subsidence in the basins attracted the fluvial network imparting the described N-S river direction (fig. 9). Compared with the present hydrography of the study area, it can be noted how the Ombrone and Orcia rivers mimic the late Neogene rivers in that their N-S reaches presently cut the structural thresholds that confined or isolated the $\mathrm{CB}$ and the VB. This may indicate a quiescence of the related structures at least during most part of the Quaternary.

\section{THE UPPER MESSINIAN DEPOSITS OF THE CB AND VB IN THE FRAME OF THE MESSINIAN SALINITY CRISIS}

A final consideration concerns the possible correlation of the late Messinian-earliest Zanclean fluvial dynamics of the study area within the regional events that characterized the Messinian Salinity Crisis (MSC; ROVERI et alii, 2014 for a synthesis; fig. 3). The high-relief compound unconformity bounding the CB2 and VB paleovalley fills may have some affinity with the Messinian Erosional Surface (MES; RovERI et alii, 2014; fig. 3), delimiting at a Mediterranean scale, the shallow-water Primary Lower Gypsum and basinal equivalent deposits from the post-evaporitic units (fig. 3). Under this assumption, the paleovalley fills would be correlated to the P-ev2 (stage 3b, Roveri et alii, 2014; fig. 3), which at a regional scale includes almost terrigenous, fluvialrelated deposits (Roveri et alii, 2014). The magnetostratigraphic record of the CB2 synthem indicates a continued fluvial activity across the Messinian-Zanclean boundary and only later, during the early Zanclean, the sea invaded the former continental areas (Bossio et alii, 1991). This conclusion implies a diachronous post-MSC continental-marine transition in the study area, which contrasts with the nearly synchronous transgression at the Messinian-Zanclean boundary recorded elsewhere in the Mediterranean Basin (Roveri et alii, 2014). Such a synchronicity has been clearly documented only in the westernmost (presently seaward) onshore Tuscan basins (RIFORGIATO et alii, 2011) whereas in the inner portion of the Northern Apennines continental, mostly fluvial, conditions, as those documented by CB2 synthem, persisted up to the earliest Pliocene (cf. ABBAZzI et alii, 2008). This suggests that the Tuscan basins were more strongly influenced by the local active tectonism of a collisional orogen rather than by the eustatic, climatic and distant geodynamic events that affected the Mediterranean Basin during the late Messinian.

\section{CONCLUSIVE REMARKS}

Facies analysis, structural, magneto-stratigraphic and paleontological data provide arguments to preliminarily constrain the common tectono-sedimentary evolution of the Cinigiano-Baccinello and Velona basins discussed in previous disctinct studies. This allows us to infer that since the late Tortonian, particularly during the Messinian to at least the early Pliocene, the area was affected by compressive tectonics that strongly conditioned the physiography as well as the hydrography of this sector of the Northern Apennines. Stages of activity of thrust faults and related anticlines delimiting the two basins created the conditions for internal drainage, favouring the development of palustrine-lacustrine settings or endhoreic alluvial plains. Periods of low or quiescient tectonics were accompanied by fluvial incision of structural thresholds and the development of a south-directed drainage system. The described tectono-depositional history of these basins occurred during the regional-scale dramatic event of the Messinian Salinity Crisis and particularly during its latest stage.

\section{ACKNOWLEDGEMENTS}

The authors wish to thank, Fabrizio Piana and an anonymous reviewer for their useful comments that greatly helped to improve the manuscript. William Cavazza is thanked for his editorial assistance. Magnetostratigraphic analyses and fieldwork were supported by funds from the Università di Firenze (Fondi di Ateneo, 2013) and CNR, Istituto di Geoscienze e Georisorse, UOS Firenze.

\section{REFERENCES}

Abbazzi L., Benvenuti M., Ceci M.E., Esu D., Faranda C., Rook L. \& TANGOCCI F. (2008) - The end of the Lago-Mare time in the SE Valdelsa Basin (Central Italy): interference between local tectonism and regional sea-level rise. Geodiversitas, 30 (3), 611-639.

Allen P.A. \& Heller P.L. (2012) - Dispersal and preservation of tectonically generated alluvial gravels in sedimentary basins. In C. Busby \& A. Azor Peres (eds.), Tectonics of Sedimentary Basins, Recent Advances, 111-130, Wiley-Blackwell.

Angelone C., Colombero S., Esu D., Giuntelli P., Marcolini F., Pavia M., Trenkwalder S., Van Den Hoek Ostende L.W., Zunino M. \& Pavia G. (2011) - Moncucco Torinese, a new postevaporitic Messinian fossiliferous site from Piedmont (NW Italy). Neues Jahrbuch für Geologie und Paläontologie-Abhandlungen, 259 (1), 89-104.

Balestrieri M.L., Pandeli E., Bigazzi G., Carosi R. \& MontoMOLI C. (2011) - Age and temperature constraints on metamorphism and exhumation of the syn-orogenic metamorphic complexes of Northern Apennines, Italy. Tectonophysics, 509, 254-271.

Bally A.W., Burbi L., Cooper C. \& Ghelardoni R. (1986) - Balanced sections and seismic reflection profiles across the Central Apennines. Mem. Soc. Geol. It., 35, 257-310.

Benvenuti M., Papini M. \& Rook L. (2001) - Mammal biochronology, UBSU and paleoenvironment evolution in a post-collisional basin: evidence from the Late Miocene Baccinello-Cinigiano basin in southern Tuscany, Italy. Boll. Soc. Geol. It., 120, 97-118.

Benvenuti M., Del Conte S., Scarselli N. \& Dominici S. (2014) Hinterland basin development and infilling through tectonic and eustatic processes: Latest Messinian-Gelasian Valdelsa Basin, Northern Apennines, Italy. Basin Research, 26, 387-402.

Bernini M., Boccaletti M., Moratti G., Papani G., Sani F. \& TORELli L. (1990) - Episodi compressivi neogenico-quaternari nell'area estensionale Tirrenica nord-orientale. Dati in mare e a terra. Mem. Soc. Geol. It., 45, 577-589.

Boccaletti M. \& Guazzone G. (1972) - Gli archi appenninici, il mar Ligure ed il Tirreno nel quadro della tettonica dei bacini marginali retro-arco. Mem. Soc. Geol. It., 11, 201-216.

Boccaletti M., Elter P. \& Guazzone G. (1971) - Plate tectonic models for the development of the Western Alps and Northern Apennines. Nature Physics Science, 34, 108-111.

Boccaletti M., Bonini M., Moratti G. \& Sani F. (1999) - Compressive Neogene-Quaternary tectonics in the hinterland area of the Northern Apennines. J. Petr. Geol., 22, 37-60.

Boccaletti M., Cerrina Feroni A., Martinelli P., Moratti G., Plesi G. \& SANI F. (1992) - Late Miocene-Ouaternary compressive events in the Tyrrhenian side of the Northern Apennines. Annales Tectonicae, 6, 214-230. 
BONINI M. \& SANI F. (2002) - Extension and compression in the Northern Apennines (Italy) hinterland: Evidence from the late Miocene-Pliocene Siena-Radicofani Basin and relations with basement structures. Tectonics, 21, 1-1; 1-35.

Bonini M., Moratti G. \& SANI F. (1999) - Evolution and depocentre migration in thrust-top basins: inferences from the Messinian Velona Basin (Northern Apennines, Italy). Tectonophysics, 304, 95-108.

Bonini M., Boccaletti M., Moratti G. \& Sani F. (2001) - Neogene crustal shortening and basin evolution in Tuscany (Northern Apennines). Ofioliti, 26 (2a), 275-286.

Bonini M., Sani F., Stucchi E.M., Moratti G., Benvenuti M., MeNANNO G. \& TANINI C. (2014) - Late Miocene shortening of the Northern Apennines back-arc. Journal of Geodynamics, 74, 1-31.

Bortolotti V., Passerini P., SAgri M. \& Sestini G. (1970) - The miogeosynclinal sequences. In: G. Sestini (ed.), Development of the Northern Apennines geosyncline. Sedim. Geol., 4, 341-444.

Bossio A., Costantini A., Foresi L., Mazzei R., Monterforti B. SALVATORINI G. \& SANDRElli F. (1991) - Notizie preliminari sul Pliocene del bacino del medio Ombrone e della zona di Roccastrada. Atti Soc. Tosc. Sci. Nat., Mem. A, 98, 259-269.

Bossio A., Costantini A., Lazzarotto A., Liotta D., Mazzanti R. Mazzei R., Salvatorini G. \& Sandrelli F. (1993) - Rassegna delle conoscenze sulla stratigrafia del Neoautoctono toscano. Mem. Soc. Geol. It., 49, 17-98.

BRogi A. (2011) - Bowl-shaped basin related to low-angle detachment during continental extension: the case of the controversial Neogene Siena Basin (central Italy, Northern Apennines). Tectonophysics, 499, 54-76.

Brogi A. \& LiottA D. (2008) - Highly extended terrains, lateral segmentation of the substratum, and basin development: The middle-late Miocene Radicondoli Basin (inner northern Apennines, Italy). Tectonics, 27, TC5002.

Brogi A., Lazzarotto A., Liotta D. \& CROP 18 Working Group (2005) - Structural features of southern Tuscany and geological interpretation of the CROP 18 Seismic Reflection Survey (Italy). In: A. Brogi, A. Lazzarotto, D. Liotta (eds.), Results of the CROP 18 Project. Bollettino della Società Geologica Italiana, Spec. 3, 213-236.

CAMPani G. (1873) - I combustibili fossili della provincia di Siena in servigio dell'industrie - Memoria seconda. Tipografia Mucci, Siena, $30 \mathrm{pp}$

Carmignani L. \& Kligfield R. (1990) - Crustal extension in the Northern Appennines: the transition from compression to extension in the Alpi Apuane Core Complex. Tectonics, 9, 1275-1303.

Carmignani L., Decandia F.A., Fantozzi P.L., Lazzarotto A. LiOTTA D. \& MECCHERI M. (1994) - Tertiary extensional tectonics in Tuscany (Northern Apennines, Italy). Tectonophysics, 238 295-315.

Carminati E. \& Doglioni C. (2012) - Alps vs. Apennines: the paradigm of a tectonically asymmetric Earth. Earth-Science Reviews, 112, 67-96.

Carta geologica della Toscana (2010) - Foglio 332 - Scansano, Sezione 332020, 1:10.000 scale. Regione Toscana, 2010.

CASSINIS R., SCARASCIA S. \& LozeJ A. (2005) - Review of seismic Wide-Angle Reflectio-Refraction (WARR) Results in the Italian Region (1956-1987). Chapter 2 - Lithospheric tectonostratigraphic setting of the Ligurian Sea - Northern Apennines-Adriatic Foreland from integrated CROP Seismic Data. In: Finetti I.R. (ed.) CROP Project - Deep seismic exploration of the Central Mediterranean and Italy. Atlases in Geoscience, Elsevier, Amsterdam, 1, $31-55$

Cavallo O., Sen S., Rage J.C. \& Gaudant J. (1993) - Vertébrés messiniens du faciés a Congéries de Ciabòt Cagna, Corneliano d'Alba (Piémont, Italie). Rivista Piemontese Storia Naturale, 14, 3-22.

CAVINI L. (2010) - Il paleodrenaggio nell'area di Baccinello-Cinigiano (GR) tra il Messiniano e il Quaternario: analisi stratigrafico-sedimentologica e revisione della letteratura. Unpublished Thesis, Università degli Studi di Firenze.

Colombero S., Angelone C., Bonelli E., Carnevale G., Cavallo O. Delfino M., Giuntelli P., Mazza P., Pavia G., Pavia M. \& RePETTO G. (2014) - The upper Messinian assemblages of fossil vertebrate remains of Verduno (NW Italy): Another brick for a latest Miocene bridge across the Mediterranean. Neues Jahrbuch für Geologie und Paläontologie-Abhandlungen, 272, 287-324.

Della Vedova B., Bellani S., Pellis G. \& Souarci P. (2001) - Deep temperatures and surface heat flow distribution. In: Vai G.B. \& Martini I.P. (eds.), Anatomy of an orogen the Apennines and adjacent Mediterranean basins. Kluwer, Dordrecht, 65-76.

Damiani A.V., Gandin A. \& Pannuzi L. (1980) - Il bacino lacustre neogenico della Velona. Mem. Soc. Geol. Ital., 21, 273-279.

Faccenna C., Funiciello F., Giardini D. \& Lucente P. (2001) Episodic back-arc extension during restricted mantle convection in the central Mediterranean. Earth Planet. Sci. Lett., 187, 105-116.

Finetti I.R., Boccaletti M., Bonini M., Del Ben A., Geletti R., PIPAN M. \& SANI F. (2001) - Crustal section based on CROP seismic data across the North Tyrrhenian-Northern ApenninesAdriatic Sea. Tectonophysics, 343, 135-163.

GELMINI R. (1969) - Ricerche geologiche nel gruppo di M. Leoni (Grosseto, Toscana). I. La geologia di M. Leoni tra Montepescali e il fiume Ombrone. Mem. Soc. Geol. It., 8, 765-796.

GHeTti P. (1998) - I bacini neogenici della Toscana Meridionale: analisi sedimentologica dei sistemi deposizionali delle prime fasi di sviluppo. Unpublished $\mathrm{PhD}$ Thesis, Università degli Studi di Firenze.

Ghetti P., Anadon P., Bertini A., Esu D., Gliozzi E., Rook L. \& SOULIE-MARsche I. (2002) - The Early Messinian Velona basin (Siena, central Italy): paleoenvironmental and paleobiogeographical reconstructions. Palaeogeography, Palaeoclimatology, Palaeoecology, 187, 1-33.

GHINAssi M. (2007) - Pliocene alluvial to marine deposits of the Val d, aly): paleoenvironme Apennines, Italy): sequence stratigraphy and basin analysis. Riv. It. Pal. Strat., 113, 459-472.

JACOBACCI A. (1965) - Foglio 129 "Santa Fiora". Carta Geologica d'Italia 1:100000 (Seconda Edizione). Servizio Geologico d'Italia, 1965.

Landi B., TANini C., Sani F. \& CarobBi S. (1995) - Evoluzione geologico-strutturale del bacino di Cinigiano-Baccinello (Toscana meridionale). Studi Geol. Camerti, 1995/1, 475-488.

LiotTA D. (1996) - Analisi del settore centro-meridionale del bacino pliocenico di Radicofani (Toscana Meridionale). Boll. Soc. Geol. Ital., 115, 115-143.

Liotta D. \& SAlvatorini G.F. (1994) - Evoluzione sedimentaria e tettonica della parte centromeridionale del Bacino pliocenico di Radicofani. Studi Geol. Camerti, Vol. Spec., 1, 65-77.

MALINVERNO A. \& RYAN W.B.F. (1986) - Extension in the Tyrrhenian Sea and shortening in the Apennines as a result of arc migration driven by sinking of the lithosphere. Tectonics, 5, 227-246.

Marroni M., Moratti G., Costantini A., Conticelli S., BenveNuti M.G., Pandolfi L., Bonini M., Cornamusini G. \& LaURENZI M.A. (2015) - Geology of the Monte Amiata region, Southern Tuscany, Central Italy. Ital. J. Geosci., 134, 171-199. doi: 10.3301/ IJG.2015.13.

Marson I., Cernobori L., Nicolich R., Stoka M., Liotta D., PaLMIERI F. \& VELICOGNA I. (1998) - CROP 03 profile: a geophysical analysis of data and results. Mem. Soc. Geol. Ital., 52, 123-137.

MARTINI P.I. \& SAGRI M. (1993) - Tectono-sedimentary characteristic of Late Miocene-Quaternary extensional basins of the Northern Appenines, Italy. Earth Sci. Rev., 34, 197-233.

Mongelli F., Pialli G. \& Zito G. (1998) - Tectonic subsidence, heat flow and uplift in Tuscany: a new geodynamic and geothermal approach. Mem. Soc. Geol. Ital., 52, 275-282.

МоттA S. (1969) - Note illustrative della Carta Grologica d'Italia alla scala 1:100.000, Foglio 128 - Grosseto. Servizio Geologico d'Italia, $78 \mathrm{pp}$.

Novarese V. (1897) - Strati pontici dei dintorni di Campagnatico e Paganico (prov. di Grosseto). Boll. Soc. Geol. It., 16, 69-72.

Pasquaré G., Chiesa S., Vezzoli L. \& Zanchi A. (1983) - Evoluzione paleogeografica e strutturale di parte della Toscana Meridionale a partire dal Miocene superiore. Mem. Soc. Geol. It., 25, 145-157.

Pondrelli S., Salimbeni S., Ekström G., Morelli A., GasPerini P. \& VANNUCCI G. (2006) - The Italian CMT dataset from 1977 to the present. Phys. Earth Planet. Int., 159, 286-303.

Ricci Lucchi F. (1986) - The Oligocene to Recent foreland basins of the Northern Apennines. Spec. Publ. Int. Ass. Sediment., 8, 105-139. 
Riforgiato F., Foresi L.M., Di Stefano A., Aldinucci M., Pelosi N., Mazzei R., Salvatorini G. \& Sandrelli F. (2011) - The Miocene/Pliocene boundary in the Mediterranean area: New insights from a high-resolution micropalaeontological and cyclostratigraphical study (Cava Serredi section, Central Italy). Palaeogeography, Palaeoclimatology, Palaeoecology, 305, 310-328.

RoOK L. \& BERNOR R.L. (2013) - Hippotherium malpassii (Equidae, Mammalia) from the latest Miocene (late Messinian; MN13) of Monticino gypsum quarry (Brisighella, Emilia-Romagna, Italy). Bollettino della Società Paleontologica Italiana, 52, 95-102.

Rook L. \& GHetTi P. (1997) - Il bacino neogenico della Velona (Toscana, Italia): stratigrafia e primi ritrovamenti di vertebrati fossili. Boll. Soc. Geol. It., 116, 335-246.

Rook L., OMs O., BenVenuti M. \& PAPINI M. (2011) - Magnetostratigraphy of the Late Miocene Baccinello-Cinigiano basin (Tuscany, Italy) and the age of Oreopithecus bambolii faunal assemblages. Palaeogeography Palaeoclimatology Palaeoecology, 305, 286-294.

Roveri M., Flecker R., Krijgsman W., Lofi J., Lugli S., Manzi V., Sierro F.J., Bertini A., Camerlenghi A., De Lange G., Go- vers R., Hilgen F.J., Hübscher C., Meijer P.Th. \& Stoica M. (2014) - The Messinian Salinity Crisis: Past and future of a great challenge for marine sciences. Marine Geology, 352, 25-58.

Sani F., Moratti G., Bonini M., Landi B., Tanini C., Piccardi L. \& Menichetti B. (2001) - A transect in southern Tuscany from Baccinello basin to the Cetona ridge. Ofioliti, 26 (2a), 281-400.

SERri G., InNOCEnTI F. \& MANETti P. (1993) - Geochemical and petrological evidence of the subduction of delaminated Adriatic continental lithosphere in the genesis of the Neogene-Quaternary magmatism of central Italy. Tectonophysics, 223, 117-147.

Trevisan L. (1952) - Sul complesso sedimentario del Miocene Superiore e Pliocene della Val di Cecina e sui movimenti tettonici tardivi in rapporto ai giacimenti di lignite e di salgemma. Boll. Soc. Geol. It., 70, 65-78.

ZANCHI A. \& TozZI M. (1987) - Evoluzione paleogeografica e strutturale recente del bacino del Fiume Albegna (Toscana meridionale). Geologica Romana, 26, 305-325. 